\title{
2015
}

Working Paper

(1)1

INSTITUTO DE POLÍTIGAS Y BIENES PÚBLIGOS [IPP]

\section{MEASURING TOTAL SOCIAL INCOME OF A STONE PINE AFFORESTATION IN HUELVA (SPAIN)}

\author{
PaOla OVANDo, \\ JOSE L. OVIEDO \\ \& \\ Pablo Campos
}




\section{INSTITUTO DE POLÍTICAS Y BIENES PÚBICOS - CSIC}

Copyright $(2015$. Ovando, P. Oviedo, J. L \& Campos, P. All rights reserved.

Instituto de Políticas y Bienes Públicos

Consejo Superior de Investigaciones Científicas

C/ Albasanz, 26-28

28037 Madrid (España)

Tel: +34916022300

Fax: +34 913045710

http://www.ipp.csic.es

How to quote or cite this document:

Ovando, P. Oviedo, J. L \& Campos, P. (2015) Measuring total social income of a Stone pine afforestation in Huelva (Spain). Instituto de Políticas y Bienes Públicas (IPP) CSIC, Working Paper. 2015-01.

Available at: digital.csic.es 


\section{Measuring total social income of a Stone pine afforestation in Huelva (Spain)}

January 27,2015

\section{Paola Ovando (corresponding author)}

Marie Curie Posdoctoral Researcher, Grantham Research Institute on Climate Change and the Environment, London School of Economics and Political Science (LSE); and Institute of Public Goods and Policies (IPP), Consejo Superior de Investigaciones Científicas (CSIC).

Houghton Street I London WC2A 2AE. UK. E-mail: P.Ovando-Pol@1se.ac.uk

\section{Jose L. Oviedo}

Associate Research Professor, Institute of Public Goods and Polices (IPP) Consejo Superior de Investigaciones Científicas (CSIC) Albasanz 26-28, 28037 Madrid, Spain.E-mail: jose.oviedo@csic.es

\section{Pablo Campos}

Research Professor, Institute of Public Goods and Polices (IPP) Consejo Superior de Investigaciones Científicas (CSIC) Albasanz 26-28, 28037 Madrid, Spain.E-mail: pablo.campos@csic.es 


\title{
Measuring total social income of a Stone pine afforestation in Huelva (Spain)
}

\begin{abstract}
We estimate the total social income delivered by a simulated Stone pine (Pinus pinea L.) afforestation investment in Huelva province, Spain. We consider the following private and public products: timber, pinecones, forestry conservation services, landowner amenities, landscape conservation, public recreation and carbon sequestration services. We show how total income of each single product is distributed into the partial rewards to labor and to environmental and manufactured assets. Results demonstrate that private income accounts on average for $46 \%$ of the total social income over the entire afforestation cycle; public income comprises the remaining 54\%. This distribution is subject to variations over the afforestation cycle according to the timber and pine cones harvesting profiles and scheduled conservationist forestry operations. Our results also indicate that the production of public non-market services offset the government compensations (payments) to support the Stone pine afforestation. Finally, our applied experimental agroforestry accounting system indicates that on average $93 \%$ of the total social income over the entire afforestation cycle would be omitted if the current national system of accounts for forestry were applied to our case study.
\end{abstract}

\section{JEL classification: Q23, Q51}

Key words: Public services, private amenities, conservationist forestry, non-market valuation, environmental income.

\section{Highlights}

-We apply an experimental agroforestry accounting system to estimate the total social income delivered by market and non-market forest products.

-The total income accrued from single private and public products is distributed amongst the partial rewards to labor, environmental asset and manufactured capital.

-Non-market public services account for the larger part of the total social income accrued from the Stone pine afforestation investment.

-The production of public non-market services offsets the government payments to Stone pine afforestation and management. 


\section{Introduction}

Ecosystem services are increasingly being recalled to support and inform the design of natural resources regulation and management programs (ECC et al., 2013; MA, 2005; UN et al., 2014), but present shortcomings on ecosystem services accounting data constrict policy action. This is the case of Mediterranean countries in Europe, which governments have assigned, over the past two decades, significant amounts of public money targeting forest resources conservation $(E C C, 2009)$ and lacking of reliable spatial economic and biophysical information on the provision of ecosystem services. Ecosystem accounting emerges, in this context, as an instrument to quantify and integrate complex ecosystems bio-physical data in connection to the economic activities (Boyd and Banzhaf, 2007; Edens and Hein, 2013; ECC et al., 2013).

In this concern, an international consortium of statistical offices is working on standardizing an environmental - economic accounting framework in connection to the System of National Accounts (SNA). A recent result is the System of Environmental and Economics Accounts 2012- Central Framework (SEEA-CF) (UN et al., 2014). The SEEA-CF applies the same accounting conventions, rules and structure of the SNA for the integration of environmental and economic information (UN et al., 2014: 6). In doing so, this system restricts the comparability of its biophysical and economic indicators to the economic activities that are represented in the SNA and consequently it is typically confined to transactions (ECC et al., 2009:2). The SEEA-CF is complemented by the ongoing SEEA version on Experimental Ecosystem Accounting (EEA), which intends to develop an ecosystem accounting framework, although lacking of the international statistical standard status conferred to the SEEA-CF (ECC et al., 2013: 1).

Forests are the archetypical natural assets for broadening the production boundaries of the SNA, as they provide a bundle of market and non-market products (Campos and Caparrós, 2006; Lange, 2004; Merlo and Croitoru, 2005; Schröter et al., 2014; Vincent, 1999). Many forests products are not captured on site in formal markets and are missing in the SNA applied to forestry. The SNA restricts the forest income estimation to a narrow concept of net value added (NVA) based on a group of forestry commodities and manufactured investments (EC, 2000). The SNA structures the national accounts by economic activities and institutional sectors (e.g., households, government, and corporations) detached to the ecosystems that support them. As a consequence of this organization, some forest ecosystem products and costs that the SNA does not consider as part of the 
conventional forestry accounts may be already captured by this system. For example through the recording of governmental expenditures in forest protection and management or as an attribute of some other products that can be purchased in a market (Day, 2013). While other forest ecosystems' products such as the visitors' enjoyment in a natural park or carbon sequestration may not being represented at all in the SNA (Edens and Hein, 2013).

To overcome the limitations of these systems, in this study we apply the experimental Agroforestry Accounting System (AAS) (Campos et al., 2001; Campos and Caparrós, 2006; Caparrós et al., 2003) aiming to measure the total social income accrued from private and public uses in a simulated Stone pine (Pinus pinea L.) afforestation in Huelva province (Spain). We depart from the premise that the Stone pine plantation is a joint private and public asset, on which the production costs incurred by both the private landowner and the government have simultaneous effects on the whole forest production process. The classification of economic activities in the AAS integrates the institutional sectors that provide and consume market and non-market products into the forest ecosystem as a single functional unit. Each single activity can integrate private and public outputs and cost. Accordingly, incomes are assigned to private and public users that in our case study are consequence of a silvicultural management concerted between society (represented by the government) and the landowner.

The SEEA-EEA suggests integrating ecosystems' non-market activities within market related data in its experimental ecosystem accounts, without tackling the integration of nonmarket values into the SNA accounts. The AAS shares with the SEEA-EAA the principle that only exchange values (excluding consumer surplus) should be used for a consistent integration of market and non-market products in the ecosystem accounts (Caparros, 2010; ECC et al., 2013). Non-market products considered in this research are integrated into the forest ecosystem accounts either as simulated or imputed exchange values attending to social preferences regarding their consumption. The AAS and the SEEA-EEA, however, diverge on their conception of ecosystems. As it was indicated, the AAS conceives ecosystems as a joint private and public environmental asset that at the same time constitutes a single functional unit delivering private and public benefits and costs. The SEEA-EEA proposes alternatively: (i) to treat the ecosystem as independent institutional unit that provides services to other institutional sectors, or (ii) to conceive the ecosystems as an environmental assets used in the production process of farmers economic activity (ECC et al, 2013: 152). In both cases, the SEEA-EEA fall short of recognizing that the government and landowners holds a shared responsibility in the production process of ecosystem services (Edens and Hein, 2013). The 
practical implication of this ecosystem conception between the two accounting approaches is that the AAS proposes to reallocate the government expenses and investment that affect the supply of forest non-market public products, which challenges the SNA boundaries and structure.

The main empirical contributions of our study respect to previous AAS applications are twofold. First, the total social income for each single activity is disaggregated into the factorial contributions of labor, environmental assets and manufactured assets in the forest ecosystem production process. Second, we present a proposal to record government payments (compensations) to landowners aimed to enhance the supply of non-market ecosystem services. We admit in this case that those payments permit landowners to perform conservation forestry practices that deliver intermediate private services that are consumed in the production process of public non-market services. This approach acknowledges the joint public-private nature of the forest production process and permits us to offer a comprehensive set of accounts for private and public products. As we will argue, a major advantage of applying the AAS approach is that it balances government payments and other expenditures for the provision of non-market ecosystem services with the social preferences regarding their enjoyment or consumption.

\section{Materials and Methods}

\subsection{Case study}

We selected the countryside and coast line areas in Southern Huelva province (Andalusia, Spain) as case study. Stone pine is the dominant native forest species in Huelva, occupying 117,049 ha that represent $46 \%$ of these province forests and woodlands areas (MAAMA, 2013). Stone pine forests in Huelva form part of Mediterranean Basin countries biodiversity hotspot, which is particularly relevant for being a reservoir for a large number of endemic plant and bird species (Myers et al., 2000). The abandonment of forest management in this area is likely to increase fire risk and to favor shrub natural revegetation. This situation which would request active interventions to maintain the mosaic of trees, shrublands and rough grasslands that enhance joint production of private and public products. In this context, landowners are expected to demand public incentives to afforestation and forestry management to avoid and reverse shrub encroachment. Stone pine afforestation has been supported in Huelva province over the last decades (Montero et al., 2004), and this species is 
listed amongst the tree species available to boost sustainable forestry and to create permanent forest ecosystem (BOJA, 2008).

In our application, we assume that pines afforestation displaces dense shrub that are not leased out for grazing and hunting purposes. We use the growth and yield parameters estimated by Montero et al. (2004) for Stone pine forests located in Huelva province. We consider five site qualities, and based on them, we create an average Stone pine stand for simulation purposes (see Supplementary material).

\subsection{Total social income and environmental income measurements}

The total social income (TI) is function of the environmental inputs and assets (those given by nature), labor, and the manufactured inputs and assets (those produced by human activities) (Campos, 2013; Edens y Hein, 2013). The total income estimated by the system of national accounts is the net value added, which comprises the compensations to employees and the net operating surplus and mixed income (ECC et al., 2009). The AAS estimates the return to capital by adding the net operating margin (NOM) and capital gain (CG). Environmental and manufactured capital incomes represent the partial returns to environmental and manufactured assets, respectively, and we estimate them separately (Table 1). The capital gain (loss) indicates the monetary change born to environmental and manufactured assets, and its inclusion into the total social income equation is consistent with the Hicksian income concept, which is broadly defined as the maximum consumption potential while maintaining the capital [private and public] intact (Campos and Caparros, 2006; Hill and Hill, 2003, McElroy, 1976).

Following Campos (2013) proposal, the environmental income (EI) is quantified by single product and activity and is estimated as a residual value after labor cost (LC) and manufactured capital income (MCI) are detracted from the TI. We assume that EI can only emerge if $\mathrm{TI}>(\mathrm{LC}+\mathrm{MCI})$, being the maximum value for $\mathrm{MCI}$ equal to the normal return (i) to the average manufactured investment (IMC) allocated during the account year to obtain private or public products from the forest and LC $\geq 0$. In this application we consider a normal real return to manufactured assets of $3 \%$. In case that capital income is negative, EI would equal to zero and the negative income would be attributed to the manufactured investment. This condition is not applied to net carbon sequestration; timber and pinecones, for which growth and capital revaluations are estimated using market environmental prices (net of manufactured costs, including the normal return to manufactured capital). The carbon EI 
could take a negative value if releases of carbon dioxide surpass its sequestration in the accounting period. Similarly, timber, pinecones and carbon EI could be negative in case of relevant capital losses due to tree depletion in the period (Table 1).

Table 1 The AAS total social income, environmental and manufactured capital income identities

\begin{tabular}{|c|c|c|c|}
\hline Concept & Initials & Formula & Definitions (in alphabetical order) \\
\hline \multicolumn{3}{|l|}{ Total income estimation } & \multirow{2}{*}{$\mathrm{CA}_{\mathrm{s}}$ : gross carbon sequestration, } \\
\hline Total output & TO & $\mathrm{TO}=\mathrm{IO}+\mathrm{FO}$ & \\
\hline Total cost & $\mathrm{TC}$ & $\mathrm{TC}=\mathrm{IC}+\mathrm{LC}+\mathrm{CFC}$ & \multirow{3}{*}{$\begin{array}{l}\mathrm{CA}_{\mathrm{R}} \text { : carbon release } \\
\mathrm{Cd} \text { : capital destruction, } \\
\mathrm{CFC} \text { : consumption of fixed capital, } \\
\text { Cr: capital revaluation, }\end{array}$} \\
\hline Net operating margin & NOM & $\begin{array}{l}\mathrm{NOM}=\mathrm{TO}-\mathrm{TC} \\
\mathrm{NOM}=\mathrm{ENOM}+\mathrm{MNOM}\end{array}$ & \\
\hline Net value added & NVA & $\begin{array}{l}\text { NVA=TO-IC-CFC } \\
\text { NVA }=\text { NOM }+ \text { LC }\end{array}$ & \\
\hline Capital income & CI & $\begin{array}{l}\mathrm{CI}=\mathrm{TO}-\mathrm{TC}+\mathrm{CG} \\
\mathrm{CI}=\mathrm{EI}+\mathrm{MCI}\end{array}$ & \multirow{2}{*}{$\begin{array}{l}\text { ENOM: environmental net operating } \\
\text { margin, } \\
\text { ECG: environmental capital gain }\end{array}$} \\
\hline Capital gains & CG & $\begin{array}{l}\mathrm{CG}=\mathrm{Cr}-\mathrm{Cd}-\mathrm{PCrc}{ }^{(1)}+\mathrm{CFC} \\
\mathrm{CG}=\mathrm{ECG}+\mathrm{MCG}\end{array}$ & \\
\hline Total social income & TI & $\begin{array}{l}\text { TI=NVA+CG } \\
\text { TI=LC+EI+MCI }\end{array}$ & \multirow{2}{*}{$\begin{array}{l}\text { FO: final output, } \\
\text { GNG: gross natural growth, }\end{array}$} \\
\hline Environmental income & EI & & \\
\hline Timber growth(TBg) & $\mathrm{EI}_{\mathrm{TBg}}$ & $\begin{array}{l}\mathrm{EI}_{\mathrm{TBg}}=\mathrm{ENOM}_{\mathrm{TBg}}+\mathrm{ECG}_{\mathrm{TBg}} \\
\mathrm{ENOM}_{\mathrm{TBg}}=\mathrm{GNG}_{\mathrm{TBg}} \\
\mathrm{ECG}_{\mathrm{TBg}}=\mathrm{Cr}_{\mathrm{TBg}}-\mathrm{Cd}_{\mathrm{TBg}}-\mathrm{PCrc}\end{array}$ & $\begin{array}{l}\text { i: normal profitability rate, } \\
\text { IC: intermediate consumption, }\end{array}$ \\
\hline Pinecones (PC) & $\mathrm{EI}_{\mathrm{PC}}$ & $\begin{array}{l}\mathrm{EI}_{\mathrm{PC}}=\mathrm{ECG}_{\mathrm{PC}} \\
\mathrm{ECG}_{\mathrm{PC}}=\mathrm{Cr}_{\mathrm{PC}}-\mathrm{Cd}_{\mathrm{PC}}\end{array}$ & $\begin{array}{l}\text { IMC: immobilized manufactured } \\
\text { capital, }\end{array}$ \\
\hline Conservation forestry (CF) & $\mathrm{EI}_{\mathrm{CF}}$ & $\mathrm{EI}_{\mathrm{CF}}=0$ & IO: intermediate output, \\
\hline Private amenities (PA) & $\mathrm{EI}_{\mathrm{PA}}$ & $\mathrm{EI}_{\mathrm{PA}}=\mathrm{ENOM}_{\mathrm{PA}}=\mathrm{TI}_{\mathrm{PA}}-\mathrm{MCI}_{\mathrm{PA}}$ & LC: labor cost. \\
\hline Recreational services (RS) & $\mathrm{EI}_{\mathrm{RS}}$ & $\mathrm{EI}_{\mathrm{RS}}=\mathrm{TI}_{\mathrm{RS}}-\mathrm{LC}_{\mathrm{RS}}-\mathrm{MCI}_{\mathrm{RS}}$ & LC: labor cost, \\
\hline Landscape (LN) & $\mathrm{EI}_{\mathrm{LN}}$ & $\mathrm{EI}_{\mathrm{LN}}=\mathrm{TI}_{\mathrm{LN}}-\mathrm{LC}_{\mathrm{LN}}-\mathrm{MCI}_{\mathrm{LN}}$ & \multirow{7}{*}{$\begin{array}{l}\text { MNOM: manufactured net operating } \\
\text { margin, } \\
\text { MCG: manufactured capital gain } \\
\text { PCrc: timber work in progress } \\
\text { reclassification adjustment }\end{array}$} \\
\hline Carbon sequestration (CAs) & $\mathrm{EI}_{\mathrm{CAs}}$ & $\mathrm{EI}_{\mathrm{CAs}}=\mathrm{ENOM}_{\mathrm{CAs}}+\mathrm{ECG}_{\mathrm{CAs}}$ & \\
\hline & & $\begin{array}{l}\mathrm{ENOM}_{\mathrm{CAs}}=\mathrm{CA}_{\mathrm{S}}-\mathrm{CA}_{\mathrm{R}} \\
\mathrm{ECG}_{\mathrm{CAs}}=\mathrm{Cr}_{\mathrm{CA}}-\mathrm{Cd}_{\mathrm{CA}}\end{array}$ & \\
\hline Manufactured capital income & MCI & & \\
\hline Timber & $\mathrm{MCI}_{\mathrm{TB}}$ & $\mathrm{MCI}_{\mathrm{TB} / \mathrm{PC} / \mathrm{CA}}=\mathrm{TO}_{\mathrm{TB} / \mathrm{PC} / \mathrm{CA}}$ & \\
\hline Pines cones & $\mathrm{MCI}_{\mathrm{PC}}$ & $-\mathrm{CI}_{\mathrm{TB} / \mathrm{PC} / \mathrm{CA}^{-}}-\mathrm{CFC}_{\mathrm{TB} / \mathrm{PC} / \mathrm{CA}}$ & \\
\hline Carbon & $\mathrm{MCI}_{\mathrm{CA}}$ & $+\mathrm{CG}_{\mathrm{TB} / \mathrm{PC} / \mathrm{CA}}-\mathrm{EI}_{\mathrm{TBg} / \mathrm{PC} / \mathrm{CAs}}$ & \\
\hline Other products $(\mathrm{j})$ & $\mathrm{MCI}_{\mathrm{j}}$ & $\mathrm{MCI}_{\mathrm{j}}=\mathrm{i} * \mathrm{IMC}_{\mathrm{j}}$ & \\
\hline
\end{tabular}

Notes: ${ }^{(1)} \mathrm{PCrc}$ is an instrumental reclassification adjustment referring to the expected initial value of the timber gross natural growth that is produced in the accounting year. At the beginning of the year, the timber growth is an expectation but part of real inventories at the end of the accounting period.

Source: Own elaboration based on Campos (2013).

\subsection{SNA and AAS outputs and costs}

Private products include timber (natural growth and harvest), pinecones harvest, government compensation payments that the landowner receives from applying conservationist forestry treatments (named forestry intermediate conservation services), and non-market private amenities. Public non-market products comprise the public recreation services enjoyed by open-access visitors, and the landscape conservation and carbon sequestration services 
enjoyed by the society as a whole. Some forest uses are left out of the analysis, either due to its marginal contribution to private incomes at the case study level (grazing and hunting incomes) or due to the lack of data (natural water yield, mushroom and edible plant gathering and threatened biodiversity conservation value). Outputs and costs prices are assumed to remain constant in the future, and correspond to the year 2008. Market prices are estimated as exchange values (quantity time price) in both the SNA and AAS systems. For non-market products the AAS makes use of simulated or imputed exchange values (Caparrós et al., 2003, Caparrós, 2010).

The SNA offers the net value added from the forestry production account $\left(\mathrm{NVA}_{\mathrm{SNA}}\right)$, in that particular case without including subsidies and taxes on production. The SNA records on the output side the sales, own gross investment in manufactured assets, intra-consumption of market raw materials, and personal consumption, donation and payment in kind of market products. On the costs side, the SNA takes into account the intermediate consumption (purchased raw materials and services plus intra-consumption) and the consumption of fixed capital (e.g., buildings, plantations and machinery) over the year (EC, 2000). The AAS net value added (NVA), extends the $\mathrm{NVA}_{\mathrm{SNA}}$ estimation to the timber natural growth, the standing timber that is harvested in the year, private and public non-market products, and the government expenditures for the provision of public non-market services. The valuation criteria for these AAS additional outputs and costs are described in the following sections.

\section{Timber growth and harvest}

Our approach to estimate the timber natural growth (NGt) follows Caparrós et al (2003). This output is valued as: $N G t=p_{p}^{\prime} g_{s}$; where $p_{p}^{\prime}$ is a vector of the expected environmental prices and $g_{s}$ is a vector of the timber growth $\left(\mathrm{m}^{3}\right.$ year $\left.{ }^{-1}\right)$ for each one of the diameter classes standing at the end of the accounting year:

$$
\begin{aligned}
& p_{p}^{\prime}=\left(p_{p}^{1}, p_{p}^{2}, \ldots, p_{p}^{d}, \ldots p_{p}^{m}\right) \\
& \text { Being: } \quad p_{p}^{d}=\sum_{j=d}^{m} \frac{\left(p_{w}^{j}-p_{k}^{j}\right) \cdot \pi_{j d}}{(1+r)^{\left(t_{j}-t_{d}\right)}} \text { for each } d=(1,2, \ldots, \mathrm{m}\}
\end{aligned}
$$

Where $p_{p}^{d}$ includes for each one of its $m$ rows the forest gate price of timber $\left(p_{w}^{j}\right)$ minus the expected manufactured cost $\left(p_{k}^{j}\right)$ per cubic meter in a diameter class $d$. This expected 
manufactured cost accounts for the timber harvesting and silvicultural treatments (those intended to enhance the timber yield) that are scheduled for the years that are left before reaching the harvesting age and for a normal return to the manufactured immobilized capital involved in the timber production process. This vector of expected environmental prices is affected by the conditional probability $\left(\pi_{j d}\right)$ that a tree that is alive in a diameter class $d$ is logged at each one of the $j$ diameter classes that are to be reached $\left(\pi_{j d}=\operatorname{Pr}(j / d), j \geq d\right)$. The number of trees that are alive at each diameter class are estimated using a survival function that depends on natural mortality, fire risk rates and the scheduled timber logging for Stone pine forest in the Huelva Province. Finally, $r$ is the discount rate, and $t_{j}$ and $t_{d}$ the age (in years) of a tree belonging to the diameter classes' $j$ and $d$, respectively. We use a real discount rate of $3 \%$ although results are evaluated considering their sensitivity to rates ranging from $2 \%$ to $6 \%$ (OCDE, 2009: 113).

The standing value of the timber that is harvested in the accounting year is recorded as an intermediate cost in the form of work-in-progress used (WPu). WPu is valued at the beginning of the accounting period as: $\delta\left(p_{w}-p_{h}\right)^{\prime} q_{h}$, where $p_{h}$ is a vector of the harvest cost for each diameter class; $\delta$ is the discount factor $[\delta=1 /(1+r)]$; and $q_{h}$ is the quantity of the harvested timber.

\section{Payments for forestry conservation services}

The landowner benefits from the direct government payments for adopting conservationist forestry practices. It is accepted that these payments are intended primary to increase the supply of environmental services (i.e.: threatened biodiversity preservation, cultural landscape conservation and climate change mitigation) (ECC, 2009). The format of those payments may be diverse, as a onetime payment or annual payments. In this simulated case study, we consider Andalusia government (one-time) payments to landowners for accomplishing an afforestation investment and to other ordinary forestry, such as thinning, pruning, shrubs clearing and leftovers elimination, which are also subject to government compensations to sustainable forest management (BOJA, 2008).

The outputs and costs of the conservationist forestry practices are accounted in private forestry activity as a single use that is under the responsibility of the landowner. Afforestation investment is recorded as a gross fixed capital formation item. The annual consumption of 
fixed capital associated with this investment ${ }^{1}$ is after recorded as an intermediate output (conservation services) that forestry provides for the production of public non-market services. In the case of ordinary forestry operations, government payments to the landowner for carrying out those practices are recorded entirely as intermediate outputs. Both types of intermediate outputs are equally shared out as intermediate costs for the production of landscape, carbon and public recreational services.

The compensation payments may not equal the production costs of forestry operations, depending on whether the amount anticipated by the government for each practice is surpassed or not. It is admitted that enhancing the provision of public non-market services is the main government objective for encouraging conservationist forestry practices; although they also affect the production function of market products such as timber and pinecones. Thus, if the total cost afforded by the landowner for applying a forest conservationist practice is higher than the compensation, the associated negative net operating margin will affect the private forestry incomes.

\section{Private amenities}

Private (non-industrial) forest landowners benefit from the consumption of amenities (e.g., recreation, life-style and heritage values) as non-market products from the land. To obtain a monetary value for these amenity products, we need to apply non-market valuation techniques or use available valuations for similar non-market products. In this paper, we make use of the results of a contingent valuation (CV) survey applied to estimate the value of landowner private amenities of Los Alcornocales Natural Park (ANP) in the Cadiz Province (Campos et al. 2009). The ANP includes mainly cork oak but also stone pine forests, shrubs and pasturelands. These woodlands are close (no more than $150 \mathrm{~km}$ ) to our case study area, and forest private amenity values could be similar. Cork oak and Stone pines are frequent species in the forests of Southwest Andalusia provinces (Cadiz, Huelva and Seville) and in many cases they are found as mixed stands.

This CV survey (64 interviews with landowners) estimated, in 2002, the maximum amount of money that the woodland owners were willing to give up (to pay) annually before selling their property to invest in a more profitable (in money terms) non-agrarian asset. This willingness to pay (WTP) is $€ 213 \mathrm{ha}^{-1} \mathrm{and} \mathrm{year}^{-1}$ (Campos et al., 2009) and represents the

\footnotetext{
${ }^{1}$ Plantation investment costs are amortised over the entire rotation of the Stone pine forest (120 yr.).
} 
output value of the landowner private amenities for the ANP in 2002. We assume this value to be similar to the amenity output value for the year 2008 in our Huelva case study. For this particular simulation we assume that the maximum WTP for the private amenities of each forest property could be potentially collected in a market. Thus, there would not be consumer surplus as the landowner would act as a monopolist. Under this assumption, the individual mean WTP per hectare is an exchange value. Thus, the aggregated exchange value would result from multiplying the mean WTP per hectare by all hectares of private properties of Stone pine forests in the analyzed region.

\section{Public recreation and landscapes services}

For the estimation of the monetary values of public recreation of a Stone pine forest in Huelva and its landscape conservation services (an option value for having in the future additional hectares of Stone pines), we use the results of a valuation survey addressed towards these environmental services. A choice experiment was used in this survey to estimate the WTP for these services in a simulated market. The survey was conducted through face-to-face interviews with Spanish adults ( $\geq 18$ years old) from 14 Spanish provinces in 2008. The results of these experiments are reported in Oviedo and Caparrós (2013) and Oviedo et al. (2014).

For public recreation (314 interviews), Oviedo et al. (2014) offer the WTP for a oneday visit to a forest characterized by the following attributes: the dominating tree species in the forest (Stone pine or Cork oak), the presence of infrastructures (yes or no), the presence of animals (yes or no) and the opportunity to pick mushrooms (yes or no). A payment for the access to the forest is also included, allowing for the estimation of WTP values. We use the mixed logit model presented in Oviedo et al. (2014) that uses a pooled choice and recoded ranking dataset to obtain the median WTP for a one-day visit to a forest where Stone pine is the dominating species and with no other attributes associated. This median WTP is $€ 13$ per visit $^{-1}$.

Assuming that the demand curve is linear with constant elasticity, this median WTP multiplied by half of the annual visits to the forest offers the maximum revenue that could be earned by a monopolist in the year in a hypothetical market. This corresponds to a benefit maximizing strategy if we assume that costs are constant. Under these assumptions, the value obtained is consistent with an exchange value given that the median WTP would be paid by $50 \%$ of the annual visits to the forest (Campos and Caparros, 2009; Caparrós, 2010; Caparrós 
et al., 2003). Considering the half of total visits $(13,359,885 \times 50 \%)$ estimated by Oviedo et al (2014) and that those are distributed amongst the 450,000 hectares of Stone pine forests in Spain, we obtain an output value of $€ 193 \mathrm{ha}^{-1}$ year $^{-1}$ for the public recreation services.

For the public landscape value we obtain from Oviedo and Caparrós (2013) the WTP of Spanish adults (750 interviews) for an afforestation program with Stone pines in southwestern Spain (Huelva and Cadiz Provinces). The attributes characterizing the programs were the afforestation area, which covered up to 80,000 hectares in intervals of 20,000 hectares, and the land use removed because of the afforestation, which could be either shrubland or eucalyptus stands. The experiment also included a payment, as a one-time increase in taxes, for carrying out the afforestation program. We use the estimated median WTP value per hectare for an afforestation investment covering 40,000 hectares and removing shrubland. This median WTP value stands for the present value of all future benefits derived from the landscapes services and can be converted to an annual WTP when using a proper discount rate.

The median WTP represents the amount that would be accepted by half of the population. For obtaining an aggregated exchange value, we multiply it by the total target population (Spanish individuals' $\geq 18$ years old from the provinces where the survey was conducted). We consider that this is the most appropriate scenario because an increase in taxes was used as the payment vehicle. The median WTP used is $€ 31.65$ person $^{-1}$ and it is obtained from the mixed logit model presented in Oviedo and Caparrós (2013). Multiplying this median WTP by the Andalusian adult population $(6,698,925$ persons $>18$ years old $)$, we obtain an aggregated present value for landscape services of $€ 5,301 \mathrm{ha}^{-1}$. Using a $3 \%$ social discount rate, the annual output value of the landscape services is $€ 59 \mathrm{ha}^{-1}$ year $^{-1}$.

\section{Carbon net sequestration}

Carbon gross sequestration is assessed using the tree diameter growth functions of Montero et al. (2004) and the functions that relate tree diameter with the aboveground and root biomass and carbon stock estimated by Montero et al. (2006) for Stone pines. We assume that the landowner is paid when the carbon sequestration takes place and has to pay (the same amount of money per carbon dioxide $\left(\mathrm{CO}_{2}\right)$ ton) when carbon is released, as result of tree harvesting, burning or death. In all of these cases, we assume that carbon release is instantaneous. Carbon sequestration/release is regarded as a public benefit/cost, and it is valued using the average $\mathrm{CO}_{2}$ price for the European Union Allowances (EUA), issued under the EU ETS (Emission 
Trading System) in 2008, that is $€ 22 \mathrm{tCO}_{2}^{-1}$ (SENDECO2, 2015). The EUAs may be seen as an upper bound price for forestry $\mathrm{CO}_{2}$ when compared to other market allowances and project based $\mathrm{CO}_{2}$ transactions in 2008. Nonetheless the EUA renders the best price reference since the EU ETS embraced $73 \%$ of the emission units sold in 2008 in the more industrialized countries (Capoor and Ambrosi, 2009). The EU ETS, however, does not include forestry credits, and it is a highly volatile market, which prices had oscillated from $€ 3.5 \mathrm{tCO}_{2}^{-1}$, to €l $6.5 \mathrm{tCO}_{2}^{-1}$ between 2009 and 2014 (SENDECO2, 2015). In consideration of this volatility, we further estimate the carbon social incomes for a lower bound price of $€ 3.5 \mathrm{tCO}_{2}{ }^{-1}$.

\section{Government expenditures}

Public costs include government expenditures to provide landscape services related to preventing and reducing the occurrence of forest fires and to provide public recreation services to open-access visitors. These expenditures are additional to the government payments to landowners for applying conservationist forestry treatments. Because of the lack of specific data on the government expenditures in the Huelva Stone pine area, we use the data on the expenditures and manufactured capital used by the government to provide the landscape and public recreation services in the woodlands of the ANP in 2002 (Campos et al., 2005; Oviedo et al., 2010). To update these costs to the year 2008, we consider that the government forest expenditures have increased in line to the funds that the Andalusia government has assigned to the Regional Forest Plan Implementation in 2002 and 2008 (see Supplementary material). We estimate that in 2008 government gross fixed investment in infrastructures used to provide landscape services attains $€ 6 \mathrm{ha}^{-1}$ and $€ 4 \mathrm{ha}^{-1}$ in case of public recreation. Government total production cost accrues $€ 108 \mathrm{ha}^{-1}, 88 \%$ attributed to landscape and $12 \%$ to public recreation.

\section{Results}

We estimate the contribution of single private and public products to total social income in five different accounting periods that include the afforestation year, and years 25, 50, 75 and 100 after the simulated plantation would have taken place (Fig. 1). The income results for each one of the analyzed periods reflect the investments, outcomes and costs related to forestry operations and public and private products that it is expected that an even aged Stone pine plantation would yield in a concrete year of its cycle (see Tables A.4 and A.5 in the 
Supplementary material for details). Government payments for concerted conservationist's forestry practices, tree growth and harvesting profiles are time varying variables, and affect the expected Stone pine plantation annual private and public incomes. Non-market outputs for private amenities, landscape and public recreation services are assumed to remain constant and are independent of the plantation age.

Our results show average income indicators for the entire Stone pine rotation (Figs. 1 and 2). These results differ substantially from the 25-year interval outcomes since in an average yearly basis, pinecones, carbon sequestration or timber growth values integer all the yield and growth oscillations observed along the afforestation cycle (see Supplementary material). Over the 120-year rotation the effect of government payments on private and public accounts is moderate in comparison to those years in which important conservationist forestry operations are scheduled (years 25 and 50). Finally, it is worth to mention that in the average situation timber and carbon capital gains are marginal, which makes sense given its proximity to a steady state situation in which annual harvest/release approximate the annual growth/sequestration of these products.

\subsection{Total social income distribution}

The contribution of private products to total social income is highly variable across the five analyzed accounting periods, with an average contribution of $46 \%$ over the entire rotation (Fig. 1). The influence of private and public uses on TI is closely attached to the intermediate services that are produced by the application of conservationist forestry practices and are attributed to public non-market services as intermediate production costs. The intermediate services delivered by conservationist forestry aggregates a fixed annual depreciation cost ( $€ 1 \mathrm{ha}^{-1}$ ); and a variable annual intermediate cost (ranging from $€ 0 \mathrm{ha}^{-1}$ to $€ 498 \mathrm{ha}^{-1}$ ) according to the payments anticipated by the government to forestry conservation treatments at each one of the analyzed periods (see Tables A.4 and A.5 in the Supplementary material). Timber and pine cones growth and harvest explain on average $26 \%$ of private capital income over the entire rotation, while private amenities account for $74 \%$ of private capital income (Fig. 2).

The TI delivered by non-market public products display relevant variations from negative incomes in year 50, in which a relevant intermediate cost from the application of forestry conservation practices is anticipated, to a maximum value by the year 75 when no conservationist practices are expected. Carbon is another factor that adds variability to public 
total income. Both the environmental net operating margin and capital gain associated to carbon fluctuate along the afforestation rotation.

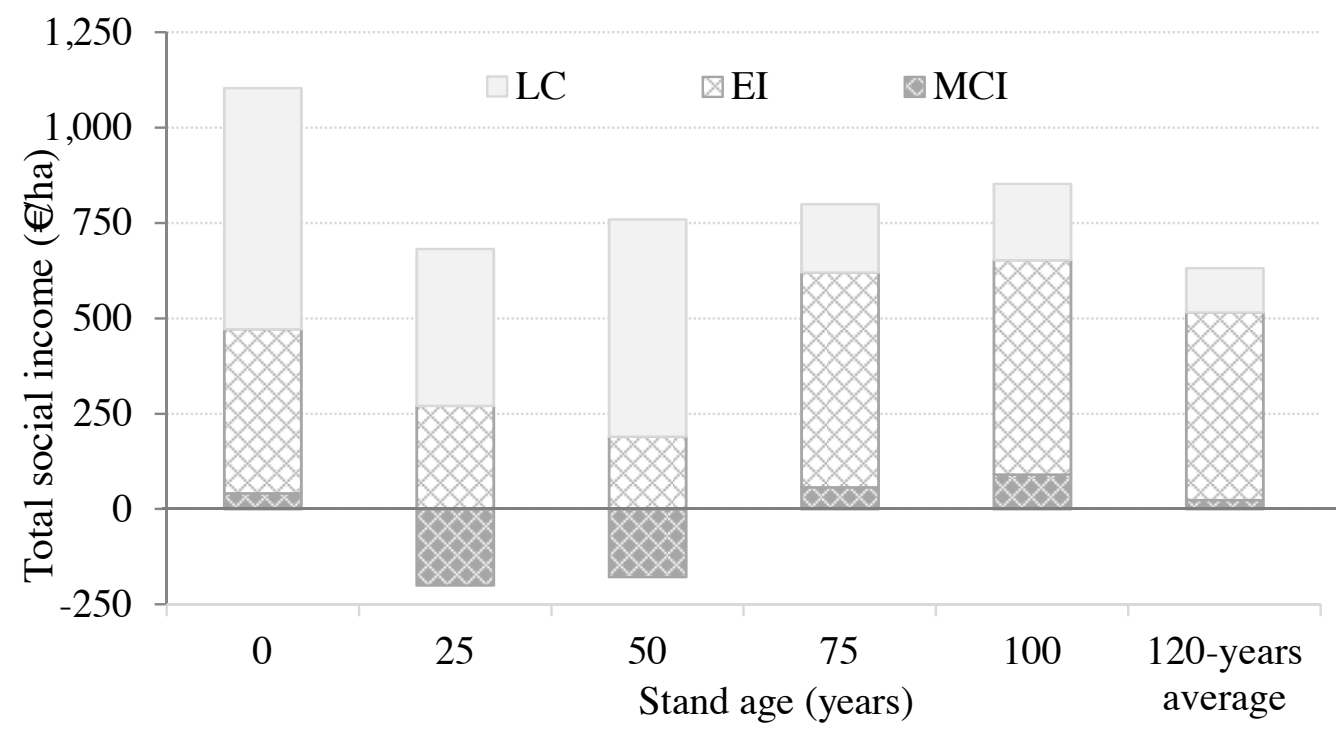

Fig. 1 Total social income distribution by Stone pines age (euro per hectare, year 2008)* *LC: labor income, EI: environmental income, MCI: manufactured capital income. Discount rate (r) applied $3 \%$.

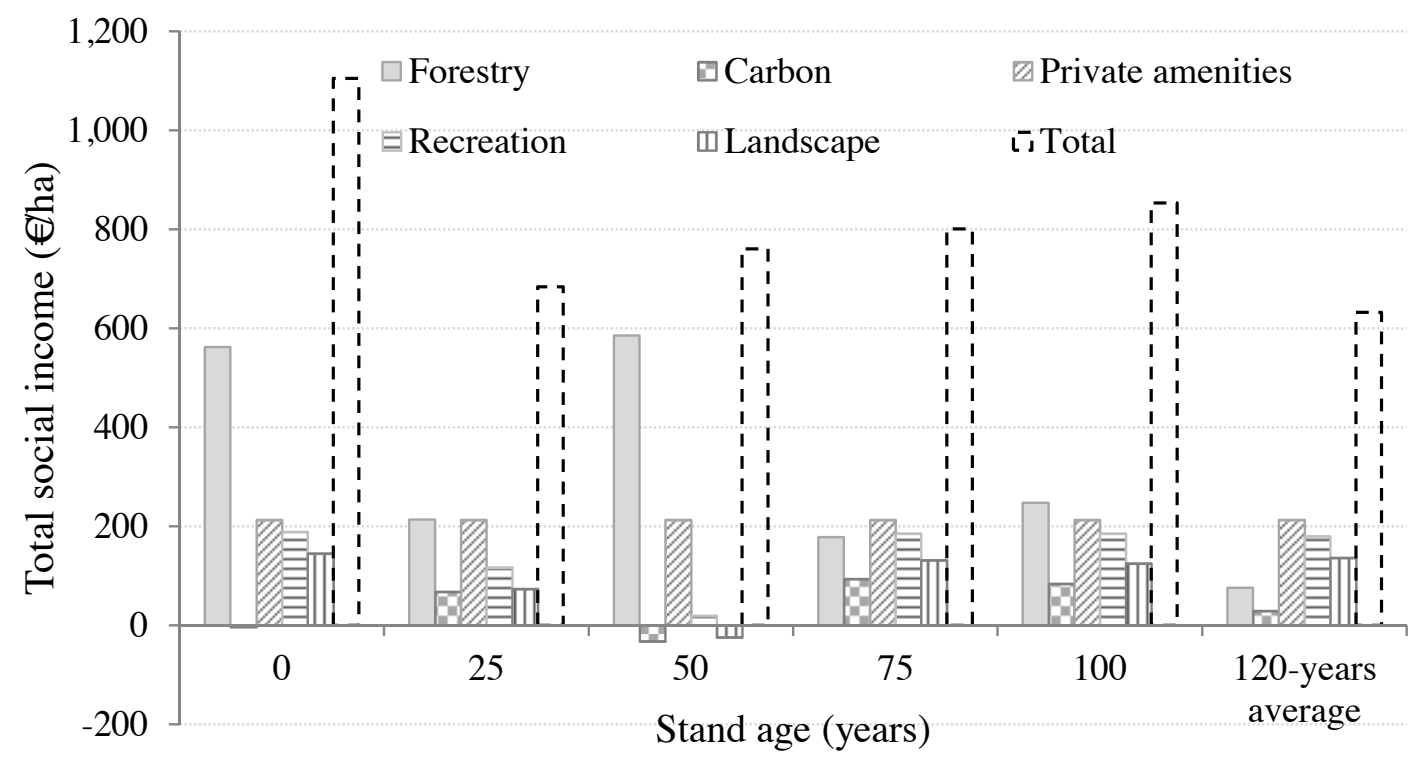

Fig. 2 Total social income by single product and Stone pines age (euro per hectare, year 2008)*

*Forestry includes timber, pinecones and conservation forestry. Discount rate applied $3 \%$. 
A negative carbon capital gain indicates an anticipated environmental asset loss, due to a decrease in carbon sequestration ability in the near term (e.g., due to a reduction in existing inventories), which affects the present value of the expected future carbon net sequestration at the end of the accounting period. On the other hand, we estimate that a lower-bound carbon price of $€ 3.5 \mathrm{tCO}_{2}^{-1}$ would reduce the average total social income associated to carbon by $130 \%$ in respect to the EUA $\mathrm{CO}_{2}$ price recorder in 2008 . The effect of the two extreme $\mathrm{CO}_{2}$ prices on our total social income estimations is however marginal, with a difference of $-4 \%$ between the higher and the lower carbon price scenarios over the entire Stone pine afforestation rotation.

The contribution of labor, environmental and manufactured asset ${ }^{2}$ as production factors varies amongst private and public uses. Labor explains from $28 \%$ to $80 \%$ of total private income across the analyzed periods, and from $17 \%$ to $28 \%$ of total public uses income. Private amenity is the main contribution of private environmental assets (land and existing tree inventories), while timber growth and capital gain slightly accounts for $6 \%$ of the private environmental income. On average, $77 \%$ of total social income delivered by public uses would be a return to public environmental asset (see Supplementary material).

The estimated total social income is relatively sensitive to the discount rate applied (Fig. 3). The discount rate affects, on one side, the estimation of capital gains and on the other side, the landscape output. We find that timber and carbon capital gains are less sensitive to discount rates, since we deal with long-term outputs and costs. The landscape output value would range from $€ 106 \mathrm{ha}^{-1}$ year $^{-1}$ for a discount rate of $2 \%$ to $€ 318 \mathrm{ha}^{-1}$ year $^{-1}$ for a discount rate of $6 \%$; which makes this output the major factor explaining the sensitivity of results to different discounting scenarios.

\subsection{Payments for conservationist forestry and public non market services}

The results of the AAS implementation indicate that the main benefits from Stone pine afforestation investment come from the production of public non-market services, which on average comprise $54 \%$ of total social income over the entire rotation (Fig. 2). These results also show that government payments to conservationist forestry practices would be expected

\footnotetext{
${ }^{2}$ Our capital income estimates do not include any reward to landowner's self-employed labour; rather they only remunerate to the landowner's investment.
} 
to enhance the production of public non-market forest products while increasing the private capital incomes from market products as timber and pine cones. In any case, the relevant analysis of governmental incentives to afforestation should consider the displaced land use: a dense tree-less shrubland in our case study.

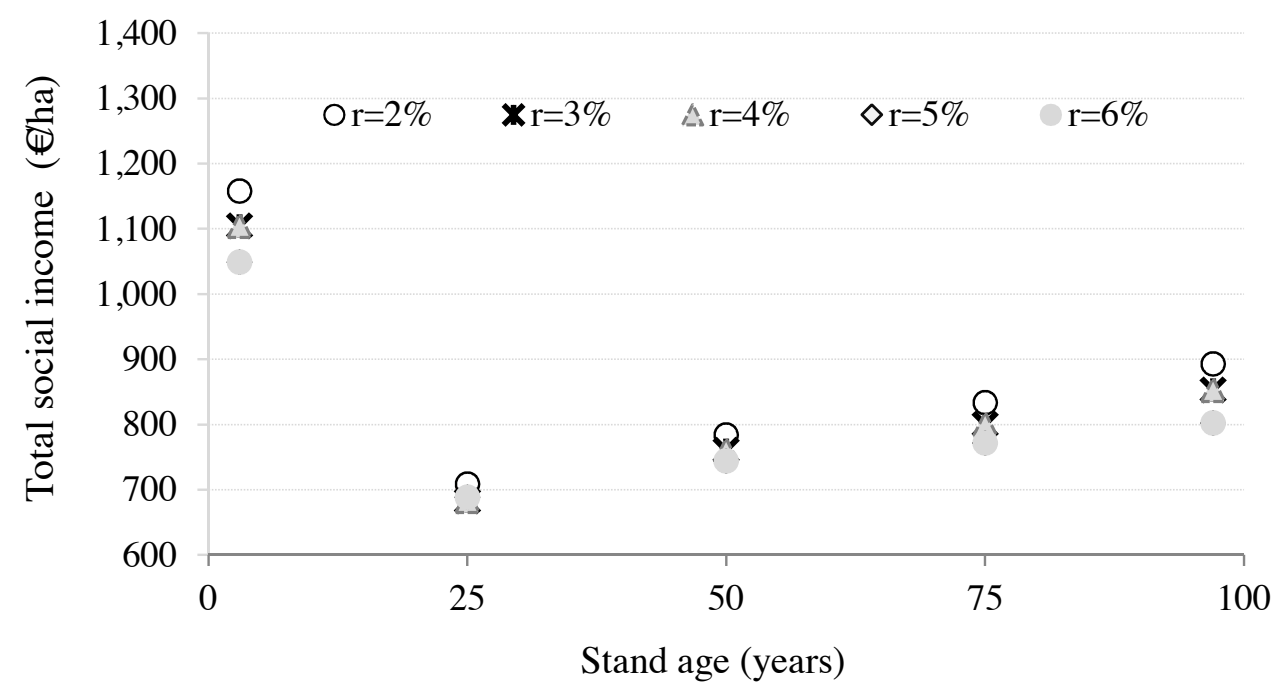

Fig. 3 Sensibility of AAS total social income to discount rates by Stone pines age (euro per hectare, year 2008)

We estimate that on average a tree-less shrubland is able to generate an average annual total social income of $€ 320 \mathrm{ha}^{-1}$, in turn made of a private income of $€ 213 \mathrm{ha}^{-1}$, and a public income of $€ 107 \mathrm{ha}^{-1}$, (see Supplementary material), which represents a $52 \%$ of the total social income that the Stone pine plantation is expected to yield on average over its rotation. The afforestation project would also increase the aggregated total private income by $35 \%$ and the public income by $211 \%$. Nonetheless, the income associated to carbon would be lower ($33 \%$ ) in the afforestation scenario respect to the initial use of the land. This result is explained by higher carbon releases due to a more intensive forestry management (i.e. tree thinning) in the afforestation scenario and by the absence of additional manufactured cost (forestry intermediate services) attributed to carbon in case the afforestation does not takes place.

Finally, is worth to mention that if we would use the average $\mathrm{NVA}_{\mathrm{SNA}}$ to evaluate the afforestation project in comparison to the initial treeless shrubland scenario, we would find that the project slightly increases the "social income" a 20\%. This estimation, as we indicate 
in the next section, would only account additional forestry sales and manufactured investments.

\subsection{SNA versus AAS total income estimations}

The AAS extensions to the official economic accounts for forest are relevant in terms of their contribution to a comprehensive total social income figure (Fig. 4). At the year of plantation, the $\mathrm{NVA}_{\mathrm{SNA}}$ accounts for $51 \%$ of the total social income, because it records the net value added from the plantation investment. For the subsequent accounting years $(25,50,75$ and 100 ), the NVA $\mathrm{ANA}_{\mathrm{SNA}}$ of forestry activity is able to capture in the best of the cases (year 100) a $18 \%$ of the total social income that a Stone pine ecosystem provides, and slightly a $7 \%$ of TI over the entire Stone pine rotation.

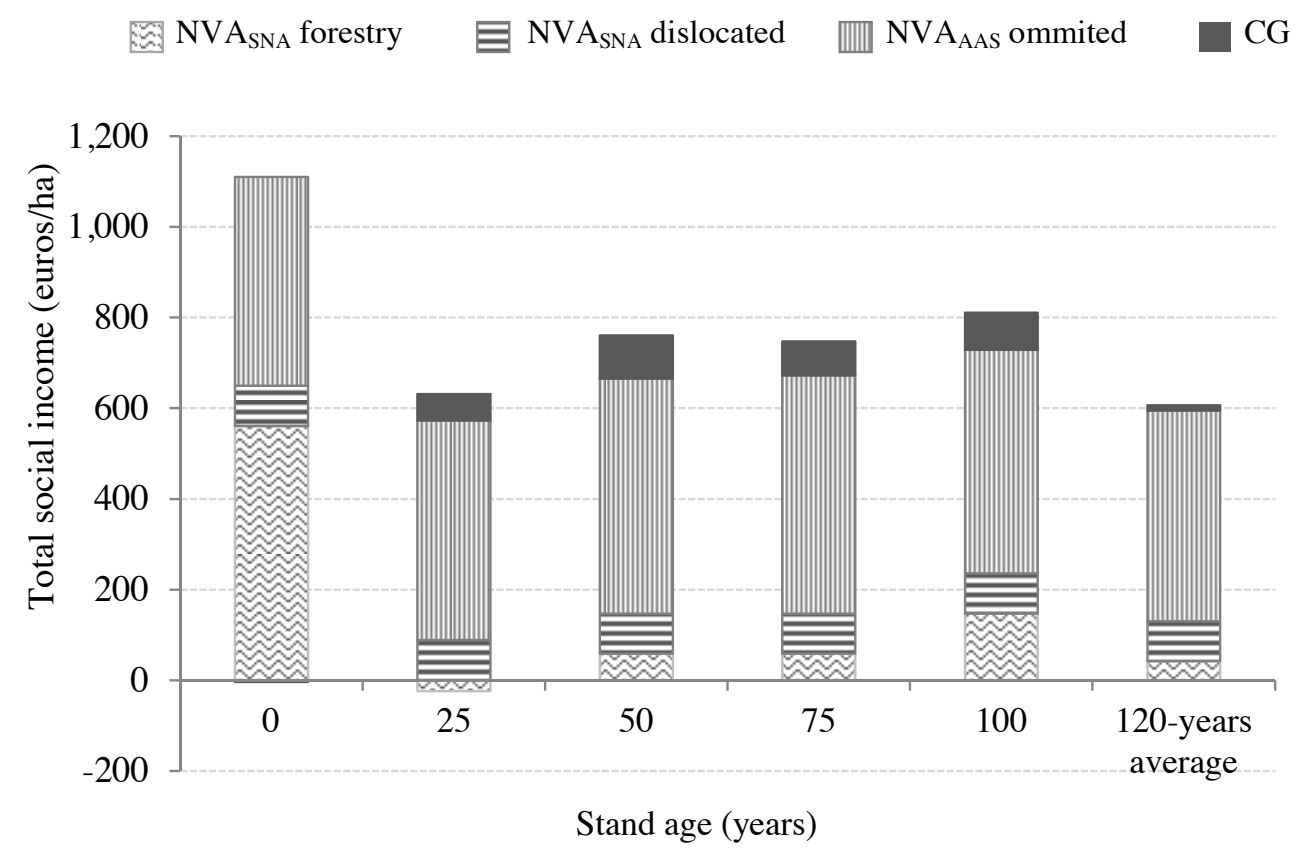

Fig. 4 SNA and AAS contribution to total social income by Stone pines age (euro per hectare, year 2008)*

*Discount rate applied 3\%.

A $93 \%$ of the total social income estimated by the AAS for the average rotation would be omitted in the SNA applied to forestry. A $14 \%$ would be dislocated into the accounts of government as institutional SNA sector, in form of gross investment and environmental 
protection services (i.e. fighting against forest fires), and taking into account that the SNA appraises those investments and services at their production costs. Hence, a relevant part of the AAS extensions to the forest net value added would be omitted (77\%) in system of national accounts, including total values of timber growth and work-in-progress used and carbon sequestration; and partially private amenities and public non-market products. Capital gains account on average for $2 \%$ of TI over the Stone pine rotation.

\section{Discussion}

\subsection{Contribution to the ecosystem accounting debate}

In this study we have estimated that a large part of the total social income delivered by a Stone pine plantation over its entire rotation would be missing in the official statistics for forestry economic accounts $\left(\mathrm{NVA}_{\mathrm{SNA}}\right)$. This situation is related to the production boundaries and the fragmentary conception of ecosystems in the SNA; but also to the difficulties and controversies regarding non-market valuation at relevant spatial scales and their coherent integration into a system of national accounts (Day, 2013, Edens and Hein, 2013).

The omission of timber natural growth, work-in-progress use and changes in timber stocks do not find a justification in the restrictions imposed by the production boundaries of the SNA, being more related to the practical implementation of the forestry economic accounts. Other proposals for extending the SNA to forest accounts, such as the Integrated Environmental and Economic Accounting for Forests (IEEAF) prompted the inclusion of timber natural growth and work-in-progress used into the production account (European Communities, 2002). Meanwhile, the SEEA-CF focuses on the estimations of timber physical and monetary environmental asset account, incorporating the timber natural growth and removal during the accounting period (UN et al., 2014). The SEEA-CF proposes to further adjust the timber $\mathrm{NVA}_{\mathrm{SNA}}$ by subtracting the value of the timber harvested over natural growth (when removals exceed normal year-on-year variations in quantities of natural growth) to estimate what in the SEEA terminology is known as the "depletion-adjusted net value added" (UN et al., 2014: 22). This SEEA-CF depletion concept does not match to the AAS capital gain, which accounts for both positive and negative variations borne from timber inventories over the accounting year.

The production boundaries of the SNA (and the SEEA-CF) restrict non-market benefits to those that accrue to economic owners, which are defined as "an institutional unit entitled to 
claim the benefits associated with the use of an asset in the course of an economic activity by virtue of accepting the associated risks" (UN et al., 2014: 47). These boundaries would include, in theory, the private amenities derived from the tenancy of woodlands and this could be partially accounted in land transactions, since private amenities are captured in the forestland market price (Campos et al., 2009). This SNA boundary challenges, nonetheless, the integration of public products for which only the government is the virtual economic owner. It is also worth to note that public recreation services, additional to the public recreation value we have estimated in this study, may be attribute of other market products that are accounted, for instance, in the tourism industry. This industry may incorporate partially recreation services from public visitors that make use of accommodation services in the visited natural area; but we do not know the part of those services that is already embedded in the SNA accounts. Forest carbon sequestration has a public good character and it is not captured currently by any single industry (Edens and Hein, 2013).

The SNA integrates partially the value of non-market products into the government SNA accounts. This sectorial account considers the ordinary expenditures and investments on forest environmental protection services afforded by governments and other economic units. As we consider that those services are valued at their production cost, we were able to estimate the labor income of these services that is already captured in the SNA government accounts (dislocated income). Ideally, those values should be reallocated to the economic activities which productions processes are being affected by government investments and expenditures, which allows the estimation of functional accounts for single forest ecosystem products.

\subsection{Incentives to enhance the provision of public non-market products}

Government payments for conservationist forestry practices are intended to encourage the provision of public non-market products, although their economic effects are implicitly displayed in private yields as timber and pinecones, as well as in the avoided damage or losses of private and public environmental assets. The AAS records as part of the private production accounts the intermediate and final outputs resulting from the application of concerted conservationist forestry treatments. In that sense, we recognize that the landowner benefits from government payments to these forestry practices. On the other hand, we also acknowledge that the society assumes a cost equal to the government payments against the 
benefits of increasing the provision of non-market ecosystem services attached to the Stone pine afforestation investment.

Current government payments for public non-market products are set in a context of insufficient information on the social preferences regarding their provision. Unless we elicit those preferences we ignore to what extent those payments capture the social benefits of nonmarket ecosystem services. In this study we offer the simulated or imputed exchange values for the landscape, carbon sequestration and public recreation as the resulting benefits of the Stone pine conservation policies. The values of the public landscape and recreational services are measured using stated preference techniques. This procedure permits the evaluation of the direct government expenditures for the provision of landscape and public recreation services and the indirect expenditures through the payments to private landowners, both involved in the production process of these services.

Our results indicate that government payments would encourage Stone pine afforestation investment that otherwise would not take place, as the market incentives to landowners are not sufficient (Ovando et al., 2010). They also assert that the government compensations and direct expenditures are offset by the Spanish households' willingness to pay for increasing the provision of public non-market services arising from the Stone pine afforestation investment, and from mitigating $\mathrm{CO}_{2}$ emissions.

We provide key economic data on landscape conservation, climate change mitigation and public recreation that should be ideally taken into account (in addition to the other ecosystem services such as biodiversity preservation or forest water yields) for designing policies aimed to concert nature conservation and societal demands. Nonetheless, in this context, it is worth to mention the uncertainty regarding positive or negative changes on water yields by shifting from a treeless shrubland to Stone pine afforestation. Evapotranspiration could vary notably between shrubland and trees, pending on site characteristics (Calder, 2003), and we ignore on what extend this changes would affect the total social income comparison between shrubland and Stone pine plantation.

\section{Conclusions}

This research presents the experimental Agroforestry Accounting Systems as an alternative approach to estimate the total social income that forest ecosystems provide. This AAS application integrates the institutional sectors of the System of National Accounts into a single multifunctional unit to include forest market and non-market activities and products. 
Our research demonstrates the SNA for forestry provides an incomplete picture if it is applied to the measurement of total social income in a Stone pine forest ecosystem. The SNA partial and fragmentary conception of ecosystems and its production boundaries restricts the information of policy relevance that this system provides for designing forest conservation incentives and regulations.

This study contributes to the current debate on extending the ecosystem accounts by highlighting the need of addressing the interactions between the private and public forest activities management decisions, and their effects on the provision of both market and nonmarket ecosystem services. In this application we estimate that non-market public products would explain more than the half of the total social income of the afforestation project, and that this project would increase the aggregated value of those products respect to the initial treeless land use. We also find that the production of public non-market products would offset the government compensations to support the Stone pine afforestation and sustainable forest management. At the same time our results suggest that landowner would increase their private incomes if the afforestation takes place.

Those results are particular for the case study, but give some insights on the potential of ecosystem accounting as a land-use planning tool. This is especially true when ecosystems are considered as functional units that supply private and public benefits to society, and which depletion affects at the end to human wellbeing. Our case study application must be seen as the benchmark for achieving a more ambitious objective: extending the SNA for forestry to a comprehensive estimation of forest ecosystem accounts at regional and national levels.

\section{Acknowledgements}

This paper received the support of the Spanish National Research Council (CSIC) research projects Bases for the sustainable management of the stands of Pinus pinea $\mathrm{L}$. in the Iberian Peninsula: ecological, silviculture models, genetic diversity and economic and social valuation of products (National RDI Plan: CPE03-001-C5), and DYNOPAGROF (SEJ200505085/ECCON). Authors are in debt with Alejandro Caparrós and Gregorio Montero for their early contribution to the environmental valuation and silvicultural models. Paola Ovando held a Research Contract at the CSIC while finishing this research. We are very gratefully for the comments of Giles Atkinson. This paper reflects only the author's views and not the views of the supporting institutions. 


\section{References}

Boletín Oficial de la Junta de Andalucía (BOJA), 2008. Orden de 25 de febrero de 2008, por la que se establecen las bases reguladoras de la concesión de ayudas para la gestión forestal sostenible de los montes en el ámbito de la Comunidad Autónoma de Andalucía. BOJA 21, de 19 de junio de 2008, 6-43.

Boyd, J., Banzhaf, S., 2007. What are ecosystem services? The need for standardized environmental accounting units. Ecological Economics 63, 616-626.

Caapor, K., Ambrosi, P., 2009. State and trends of the carbon market 2009. The World Bank. Washigton D.C.

Calder, I. R., 2003. Assessing the water use of short vegetation and forests: Development of the hydrological land use change (HYLUC) model. Water Resources Research 39(11), SWC51-SWC58.

Campos, 2013. Renta ambiental del monte. Proceedings of the 6th Spanish Forestry Conference. Available online: http://www.congresoforestal.es/actas/doc/6CFE/ 6CFE02004.pdf.

Campos, P., Caparrós, A., 2006. Social and private total Hicksian incomes of multiple use forests in Spain. Ecological Economics 57 (4), 545-557.

Campos, P., Caparrós, A., 2009. Can we use non-market valuation techniques in green national accounting applied to forests? Austrian Journal of Forest Science 126(1-2), 5374.

Campos, P., Rodríguez, Y., Caparrós, A. 2001. Towards the Dehesa total income accounting: theory and operative Monfragüe study cases. Investigación Agraria: Sistemas y Recursos Forestales. Special issue on New Forestlands Economic Accounting: Theories and Applications 1, 45-69.

Campos, P., Oviedo, J. L., Caparrós, A., 2005. Un sistema de cuentas para la valoración de los efectos comerciales y ambientales del gasto público en la mitigación del fuego en el bosque mediterráneo. Investigación Agraria: Sistemas y recursos Forestales 14(1), 120131.

Campos, P., Oviedo, J.L., Caparrós, A., Huntsinger, L., Seita-Coelho, I., 2009. Contingent Valuation of Woodland-Owner Private Amenities in Spain, Portugal, and California. Rangeland Ecology and Management 62(3), 240-252. 
Caparrós, A., Campos, P., Montero, G., 2003. An operative framework for total Hicksian income measurement: application to a multiple use forest. Environmental and Resource Economics 26, 173-198.

Caparrós, A., 2010. Contabilidad Nacional Verde en el Sector Forestal. Cuadernos de la Sociedad Española de Ciencias Forestales 31, 251-262.

Day, B., 2013. An overview of valuation techniques for ecosystem accounting. Issue Paper 1.1. Valuation for Accounting Seminar 11/11/2013. Available online:file:///H:/issuepaper11dayvaluationforaccounting_tcm77-355601.pdf

Edens, B., Hein, L., 2013. Towards a consistent approach for ecosystem accounting. Ecological Economics 90, 41-52.

European Commission (ECC), 2009. Report on implementation of forestry measures under the rural development regulation 1698/2005 for the period 2007-2013. Directorate H Sustainability and Quality of Agriculture and Rural Development H.4. Bioenergy, biomass, forestry and climate change.

European Commission (ECC), International Monetary Fund, Organization for Economic Cooperation and Development, United Nations, World Bank, 2009. System of National Accounts 2008. New York.

European Commission (ECC), Food and Agriculture Organization, International Monetary Fund, Organization for Economic Cooperation and Development, United Nations, World Bank, 2013. System of Environmental and Economic Accounting-Experimental Ecosystem Accounting (SEEA-EEA).White cover publication, pre-edited text subject to official editing.

European Communities (EC), 2000. Manual on the Economic Accounts for Agriculture and Forestry EEA/EAF 97 (Rev. 1.1). European Commission, EUROSTAT, Luxembourg.

European Communities (EC), 2002. The European Framework for Integrated Environmental and Economic Accounting for Forests (IEEAF).European Commission, EUROSTAT. Luxembourg.

Hill, R. J., Hill, T.P., 2003. Expectations, capital gains and income. Economic Inquiry 41(4), 607-619.

Lange, G.M., 2004. Manual for Environmental and Economic Account for forestry: a tool for cross-sectoral policy analysis. Working Paper, FAO, Forestry Department, Rome.

McElroy, M.B., 1976. Capital gains and social income. Economic Inquiry XIV, 221-240. 
Merlo, M., Croitoru, L., 2005. Concepts and Methodology: a First Attempt Towards Quantification. In: Merlo, M., Croitoru, L. (Eds.), Valuing Mediterranean Forests: Towards Total Economic Value. CAB International, Wallingford, UK, pp. 17-36.

Millenium Ecosystems Assessment (MA), 2005. Ecosystems and Human Well-being: Synthesis. Island Press, Washington, DC.

Ministerio de Agricultura, Alimentación y Medio Ambiente (MAAMA), 2013. Tercer Inventario Forestal Nacional. Provincia de Huelva. Ministerio de Agricultura, Alimentación y Medio Ambiente. Madrid.

Montero, G., Candela, J.A., Rodríguez, A. 2004. El pino piñonero (Pinus pinea L.) en Andalucía. Junta de Andalucía. Seville.

Montero, G., Ruiz-Peinado, R., Muñoz, M., 2006. Producción de biomasa y fijación de $\mathrm{CO}_{2}$ por los bosques españoles. Monografías INIA. Serie Forestal 13. INIA. Madrid.

Myers, N., Mittermeier, R.A., Mittermeier, C.G., Da Fonseca, G.A.B., Kent, J., 2000. Biodiversity hotspots for conservation priorities. Nature 403, 853-858.

Organización para la Cooperación y el Desarrollo Económico (OCDE), 2009. Medición del capital. Manual OCDE. Second Edition.

Ovando, P., Campos, P., Calama, R., Montero, G., 2010. Landowner net benefit from Stone pine (Pinus pinea L.) afforestation of dry-land cereal fields in Valladolid, Spain. Journal of Forest Economics 16, 83-100

Oviedo J. L., Caparrós A., 2013.Comparing Contingent Valuation and Choice Modeling using field and eye-tracking lab data. Instituto de Políticas y Bienes Públicos (IPPCSIC), Working paper, Number 2013-01: 56 pp. Available at: https://sites.google.com/site/oviedojoseresearch/working-papers.

Oviedo, J. L., Campos, P., Caparrós, A., 2010. Simulated Exchange Value Method: Applying Green National Accounting to Forest Public Recreation. Instituto de Políticas y Bienes Públicos (IPP) Working paper series, Number 16. Available online: http://hdl.handle.net/10261/28915.

Oviedo, J. L., Caparrós, A., Campos, P., 2014. Testing choice experiment consistency in the valuation of forest public recreational use. Instituto de Políticas y Bienes Públicos (IPPCSIC).Working paper series, Number 014-01. Forthcoming.

Carbon dioxide emission allowances electronic trading system $\left(\mathrm{SENDECO}_{2}\right) .2015$. Historical $\mathrm{CO}_{2}$ prices for EUAs. Available online: http://www.sendeco2.com. 
Schröter, M., Barton, D. N., Remme, R. P., Hein, L., 2014.Environmental Accounting for capacity and flow of ecosystem services: A conceptual model and a case study for Telemark, Norway. Ecological Indicators 36, 539-551.

United Nations (UN), European Union, Food and Agriculture Organization of the United Nations, International Monetary Fund, Organization for Economic Cooperation and Development, World Bank , 2014. System of Environmental-Economic Accounting 2012 -Central Framework [SEEA-CF].United Nations, New York.

Vincent, J.R., 1999. A framework for forest accounting. Forest Science 45(4), 552-561. 


\section{Supplementary material to "Measuring total social income of a Stone pine afforestation in Huelva (Spain)"}

\section{Growth, production and silvicultural models}

The incomes estimated from timber and pine cones consider the growth and yield parameters of Montero et al. (2004) for Stone pine stands located in the Huelva province (Fig. A.1), including five site qualities according to the surface that they cover (Table A.1). The yields and management cost are assessed for a Stone pine forestry model that is characterized by a moderated thinning intensity and aims to favor the pinecones yield over a 120-year rotation period (Montero et al., 2008). It is assumed that after this period the natural regeneration of the aged Stone pine stand is induced by felling a large part of the pines ( $>50 \%)$ while leaving the remainder as seed-trees for ten years. It is also assumed that after 130 years the remaining mature pines are felled, and the recruited pines prompt a new Stone pine rotation with similar timber and pinecones yields as in the afforestation productive cycle.

Timber and pinecones are the main market outputs delivered by the Stone pine stand. The timber yield is estimated considering tree growth functions of Montero et al. (2004) for each one of the site qualities. The site qualities are ranked according to the dominant height that an average Stone pine reach at a reference year (Table A.1). We weight results for the Stone pine forests in Huelva province according to the estimated share of Stone pine surface of each site $(j)$ :

$$
\bar{x}=\sum_{j=1}^{J} x_{j} \cdot w_{j}
$$

Table A.1 Physical yields and attributes of Stone pine plantations according to the site quality index

\begin{tabular}{|c|c|c|c|c|c|c|}
\hline \multirow[t]{2}{*}{ Class } & \multicolumn{5}{|c|}{ Site quality index (j) } & \multirow{2}{*}{$\begin{array}{l}\text { Weighted } \\
\text { value }(\bar{x})\end{array}$} \\
\hline & 1 & 2 & 3 & 4 & 5 & \\
\hline Production cycle or rotation length (years) & 120 & 120 & 120 & 120 & 120 & 120 \\
\hline Site quality weight $\left(w_{j}\right)$ on Stone pine surface $(\%)$ & 8 & 19 & 32 & 32 & 9 & - \\
\hline Dominant height at 75 years old $(\mathrm{m})$ & 19 & 16 & 13 & 10 & 7 & 13 \\
\hline Commercial pinecone yield $\left(\mathrm{kg} \mathrm{ha}^{-1} \mathrm{year}^{-1}\right)$ & 307 & 139 & 90 & 124 & 21 & 121 \\
\hline Timber growth $\left(\mathrm{m}^{3} \mathrm{ha}^{-1}\right.$ year $\left.{ }^{-1}\right)$ & 0.8 & 0.6 & 0.4 & 0.2 & 0.1 & 0.4 \\
\hline Net carbon sequestration $\left(\mathrm{t} \mathrm{CO}_{2} \mathrm{ha}^{-1}\right.$ year $\left.^{-1}\right)$ & 2.5 & 1.8 & 1.2 & 0.8 & 0.4 & 1.2 \\
\hline
\end{tabular}

Source: Own elaboration based on Montero et al. (2004; 2008). 
Where, $x_{j}$ refers to any physical or economic variable associated to Stone pine forest within the site $j ; J$ is the number of site quality classes $(\mathrm{J}=5)$ and $w_{j}$ refers to the weight of a site quality class $j$ according to the surface that each site quality covers in the Stone pine woodlands at the province of Huelva (Table A.1).

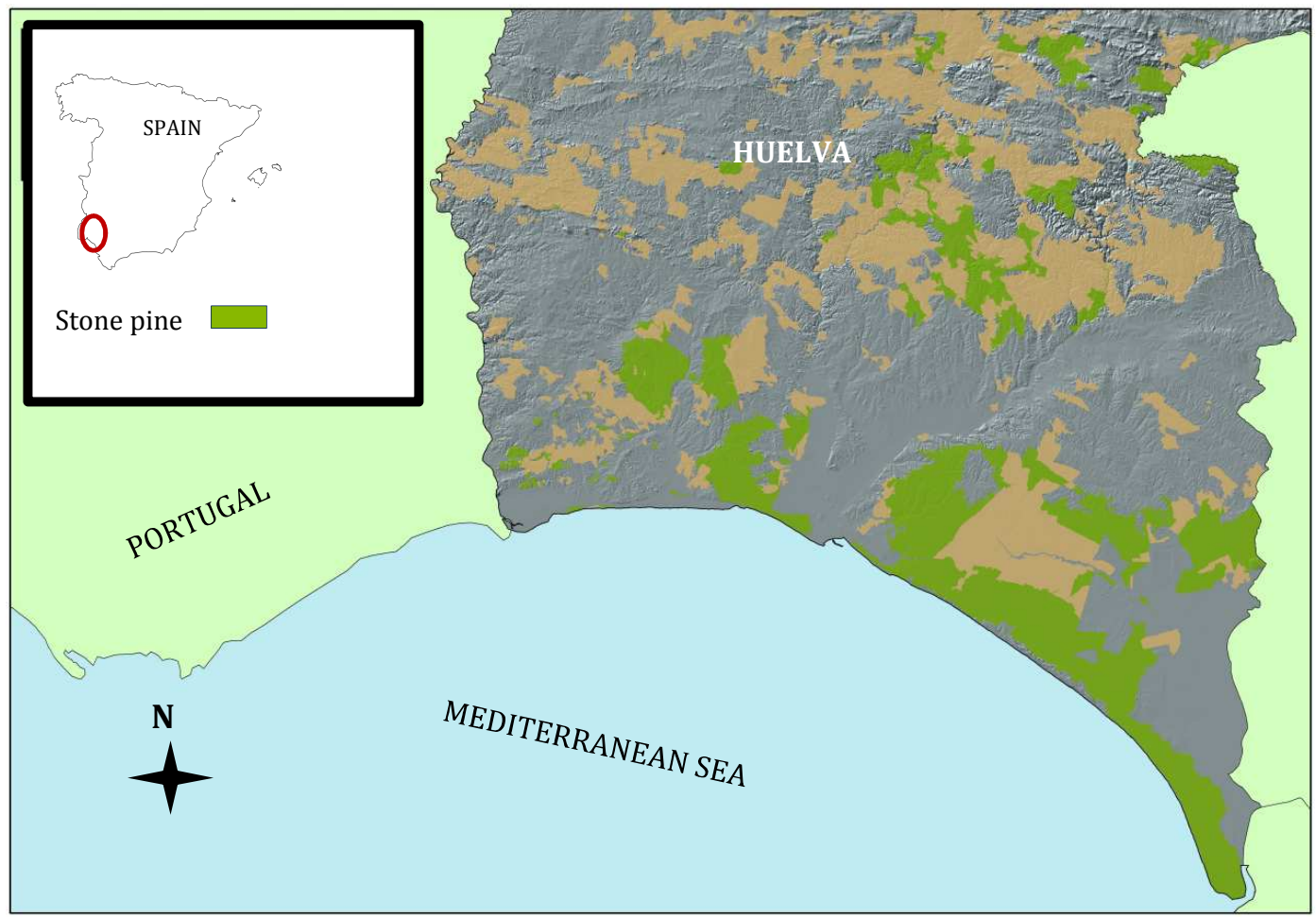

Fig. A.1. Stone pine distribution in Huelva province*.

*Data for the Second Spanish Forest Inventory (IFN2).

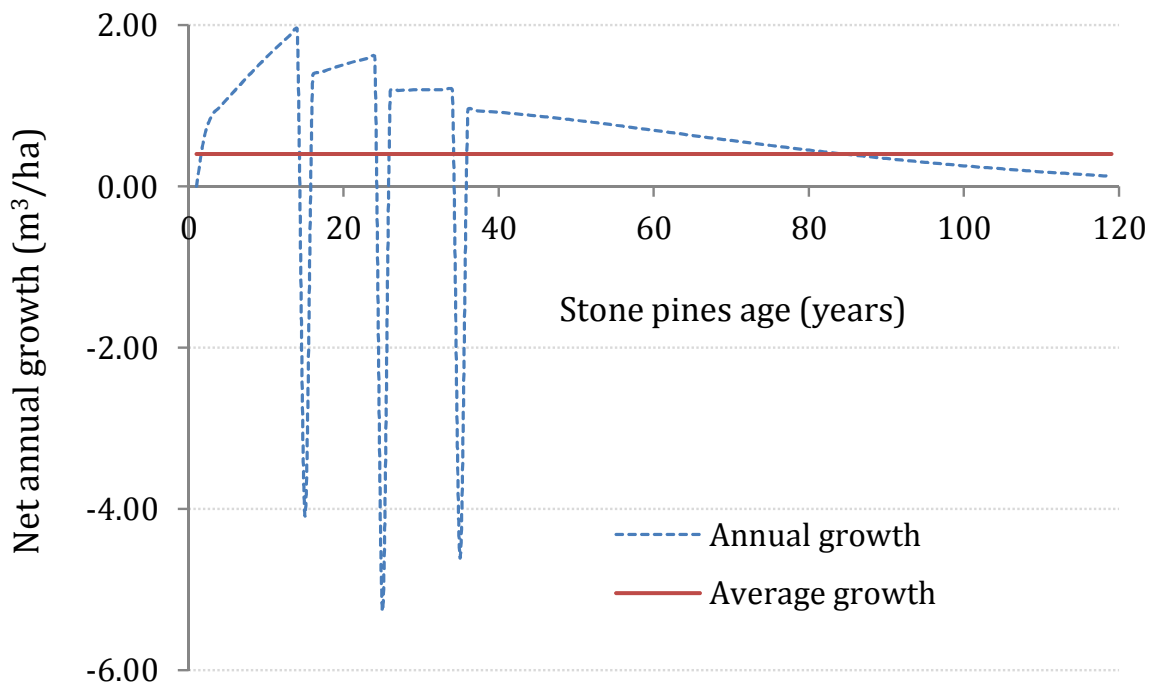

Fig. A.2. Evolution of annual timber net growth according to the Stone pines age. Data for site quality 3 
Figs. A.2 and A.3 show the expected variations in timber growth and commercial pinecone yields along the entire rotation cycle for the site quality number 3 .

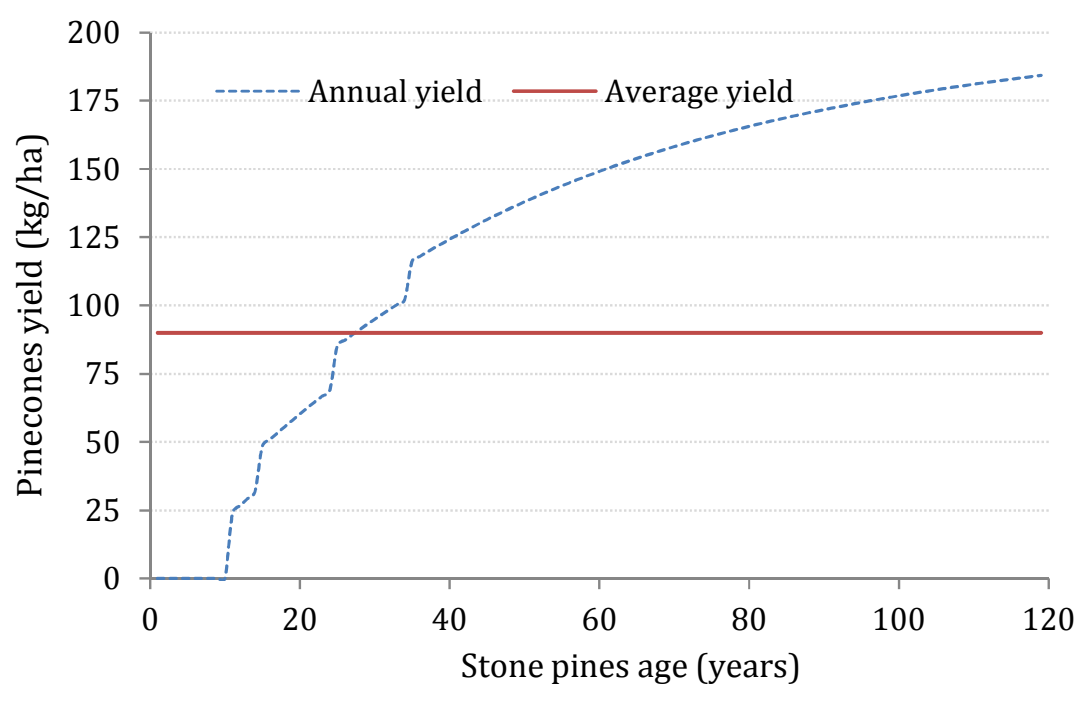

Fig. A.3. Evolution of commercial pinecones annual yields according to the Stone pines age. Data for site quality 3

\section{Market and non-market exchange prices}

2.1 Private benefits and expenditure on forest management

The private manufactured costs include afforestation and forestry operating expenditures along the entire Stone pine rotation and timber and pine cones harvesting (Table A.2). All these values were directly drawn from local market prices in 2008, and were obtained from in-depth interviews with local forestry firms and private landowners at the case study area.

\subsection{Government expenditures}

The public costs include government expenditures to provide landscape services related to preventing and reducing the occurrence of forest fires and public recreational services to open-access forests visitor. There is no specific information related to government expenditures in Huelva Stone pine area, therefore we transfer and update the expenditures that Campos et al. (2005) and Oviedo et al. (2010) estimate for an oak woodland area in Cadiz in 2002 (Los Alconocales Natural Park). For the updating procedure, we consider that the government expenditures in forest have increased within the real evolution the money that 
the government of Andalusia has assigned to the Regional Forest Plan Implementation for the period 2002-2008.

In 2002, the expenditures in the implementation of the Forest Plan accrued $€ 203,079,377$ while in 2008 to $€ 556,007,965$ (CMA, 2002; 2008). Considering the general annual consumer price index variation between 2002 and 2008 (21.5\%), the governmental expenditures on the forest resources conservation have increased in real terms a $225 \%$. Under the Forest Plan budget, the Andalusian government affords expenditures for forest resources conservation and for the provision of public recreational opportunities in forest ecosystems (CMA, 2008).

We estimate an annual governmental expenditure of 108 euro ha $^{-1}$ in $2008,88 \%$ of this budget is used to prevent and fight against forest fires which is attributed to landscape conservation services) and the remainder $12 \%$ to develop and maintain visitor centers and other infrastructure used by open access Stone pine area visitors, thus it is attributed entirely to the provision of public recreational services (Table A.2).

\subsection{Annual incomes of a tree-less shrubland}

We assume that the Stone pine afforestation displaces dense shrub that do not deliver land rents from grazing and hunting. In that case no private market incomes are associated to this previous land use, being private incomes entirely depending on the willingness to pay (WTP) for private amenities. Landscape conservation and public recreational services were estimated specifically for Stone pine forests in Spain. In the case of landscape values we estimate the simulated output value from shifting the use of land from a treeless shrub to a Stone pine plantation of 40.000 hectares as it is explained in the main text.

We have estimated the shrublands carbon net sequestration considering Navarro and Blanco (2006) functions of biomass growth for different shrub species in the Los Alconocales Natural Park (ANP). In this application, we use the growth function for Cistus ladanifer ${ }^{3}$, which is one of the main shrubs species in Andalusia, and consider a rate of 1.83 to convert biomass (dry matter weight) to a $\mathrm{CO}_{2}$ stock. We estimate on average (for a 25 years period) that Cistus ladanifer would sequester (gross sequestration) $1.49 \mathrm{t} \mathrm{CO}_{2}$ per hectare and year. The expected carbon emissions along this period depend on the annual conditional

\footnotetext{
${ }^{3}$ The biomass growth function of Cistus ladanifer is: $\mathrm{W}=0.064 \mathrm{~A} 2+79.39 \mathrm{~A}-76.42$, where $\mathrm{W}$ represent the biomass dry matter weight $\left(\mathrm{g} \mathrm{m}^{-2}\right)$, and A the shrub age (years).
} 
probability of shrubs to be cleared or burnt. In that case we consider an annual shrub clearing probability of $1.5 \%^{4}$, and an annual fire risk of $0.3 \%$, which matches to the fire risk ratio, considered for the Stone pine forest in Huelva and corresponds to the average annual share of Stone pine burnt surface in the province of Huelva over the period 1987-2006 (Diaz-Balteiro et al., in revision).

Table A.2 Unitary exchange prices for Stone pine outputs and costs (2008 euro unit ${ }^{-1}$ )

Class Unit Price (euro unit ${ }^{-1}$ )

Goods and services

Timber (stumpage price)

Diameter $<15 \mathrm{~cm}$

Diameter $15-30 \mathrm{~cm}$

Diameter $>30 \mathrm{~cm}$

$m^{3}-3$

$m^{3} \quad 13$

$m^{3} \quad 28$

Timber (forest gate price)

Diameter $15-30 \mathrm{~cm}$

Diameter $>30 \mathrm{~cm}$

Pine cones (stumpage price) (metric ton: $t$ )

Pine cones (forest gate price)

Pine cones (collection costs)

Private amenity self-consumption

Public recreational services (Period 30-125)

Carbon sequestration

Landscape services ( $\mathrm{r}=3 \%$ )

Forestry operation cost

Plantation costs (Year 0)

Shrubs clearing (Years: 3,5,15,35,50,120 )

First pruning (Year 8)

Second pruning (Year 15)

Third pruning (Year 15)

First thinning (Year 15)

Second thinning (Year 25)

Third thinning (Year 35)

Commercial harvest

$m^{3} \quad 21$

$m^{3} \quad 44$

$\mathrm{t} \quad 60$

$\mathrm{t} \quad 400$

$\mathrm{t} \quad 269$

ha year $^{-1} \quad 213$

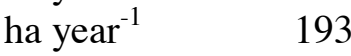

$\mathrm{t} \mathrm{CO}_{2} \quad 22$

ha year $^{-1} \quad 159$

ha $\quad 1,300$

ha $\quad 607$

ha 431

ha 388

ha $\quad 460$

$\mathrm{m}^{3} \quad 28.9$

$\mathrm{m}^{3} \quad 14.5$

$\mathrm{m}^{3} \quad 14.5$

$\mathrm{m}^{3} \quad 13.3$

Public expenditures

Landscape services

ha year

95.1

Public recreational services

ha year

Compensations to afforestation and forest management

Reforestation compensation on non-agricultural lands* (Year 0) ha 1,666

Thinning (from $10 \%$ to $20 \%$ of canopy cover)* ha 520-603

Clearing (according to the shrubs density)* ha 280-355

*Maximum amount (BOJA, 2008).

${ }^{4}$ Estimation based a survey to 765 Andalusia forest land owners (Oviedo et al., in revision). 
Government expenditures on public recreational and landscape services are also attached to the mosaic of land uses, thus equally distributed between Stone pine and tree-less shrub surfaces. On the contrary, in case of treeless shrublands no government payments for the application of conservationist forestry are considered, hence no manufactured costs associated to carbon. We estimate that on average a treeless shrubland would generate a total social income of $€ 320 \mathrm{ha}^{-1}$ year $^{-1}$ (Table A.3).

Table A.3 Total social income distribution in treeless shrubland (euro per hectare, year 2008)

\begin{tabular}{lcccccc}
\hline Class & $\begin{array}{c}\text { Private } \\
\text { market } \\
\text { products }\end{array}$ & $\begin{array}{c}\text { Private } \\
\text { amenities }\end{array}$ & $\begin{array}{c}\text { Public } \\
\text { recreation }\end{array}$ & Carbon & $\begin{array}{c}\text { Landscap } \\
\mathrm{e}\end{array}$ & Total \\
\hline 1.Labor cost (LC) & 0 & 0 & 5 & 0 & 66 & 71 \\
2. Capital income (CI) & 0 & 213 & -4 & 40 & 0 & 249 \\
2.1 Environmental (ECI) & 0 & 213 & 0 & 40 & 13 & 266 \\
2.2 Manufactured (MCI) & 0 & 0 & -4 & 0 & -13 & -17 \\
3. Total social income (TI) & 0 & 213 & 1 & 40 & 66 & 320 \\
\hline
\end{tabular}

\section{Environmental Stone pine forest assets}

The value of environmental assets is estimated considering the Net Present Value (NPV) approach. The environmental assets represent the stream of environmental incomes that are expected to be earned in the future and then discounting these environmental incomes back to the present accounting period. This valuation need previously to determine the expected pattern of environmental incomes based on extraction profiles, prices, discount rates, assets expected life, and the manufactured assets opportunity costs (ECC et al., 2013).

The environmental assets of a Stone pine forest include the capital value of the expected timber $(W P t)$ and pinecone yields along the Stone pine rotation $\left(F C b r_{c}\right)$, and the value of land without trees $(F C l)$.

\subsection{Expected timber inventories}

The expected timber inventories are recorded as work-in-progress timber $(W P t)$, which represents the value of the timber that is expected to be logged in the future. The economic value of WPt along the Stone pine rotation is estimated according to:

$W P t=p_{p}^{\prime} \cdot\left(V_{j} / V_{d}\right) \cdot q_{s}$ 
$p_{p}^{\prime}=\left(p_{p}^{1}, p_{p}^{2}, \ldots, p_{p}^{d}, \ldots p_{p}^{m}\right)$

Being: $\quad p_{p}^{d}=\sum_{j=d}^{m} \frac{\left(p_{w}^{j}-p_{k}^{j}\right) \cdot \pi_{j d}}{(1+r)^{\left(t_{j}-t_{d}\right)}}$ for each $d=[1,2, \ldots, \mathrm{m}\}$

where $p_{p}^{\prime}$ is a vector of environmental prices (unitary resource rent), $q_{s}$ is a vector of $m$ rows that records the existing timber inventories (in $\left.\mathrm{m}^{3}\right)$ in the accounting period, $\left(V_{j} / V_{d}\right) \cdot$ is an expansion factor for timber stocks that relates the unitary timber volume of a tree of a diameter class $d\left(V_{d}\right)$ and the volume of that same tree in the following diameter classes $j\left(V_{j}\right)$ to be reached (Table A.4). The conditional probability $\left(\pi_{j d}\right)$ depends on the probability that a tree of a diameter class $d$ is felled, burnt or death at each one of the subsequent diameter classes $j$ (Table A.4)

\subsection{Biological resources: expected value of pinecones harvesting}

The biological resources account for the standing value of the trees yielding repeated outputs, as pinecones. Pinecone is an annual output that is harvested depending on the proportion of yields of commercial interest (Table A.4). The economic value associated to pinecones harvesting over the Stone pine forest rotation $\left(F C b r_{c}\right)$ is estimated as:

$\mathrm{FCbr}_{c}=p_{c}^{\prime} \cdot\left[\left(Y_{j} / Y_{d}\right)\left(x_{j} / x_{d}\right)\right] \cdot q_{c}$

where $q_{c}$ is a vector of pinecone yield of commercial interest $\left(\mathrm{kg} \mathrm{year}^{-1}\right)$ for each one of the $d$ diameter classes during the accounting year, and $p_{c}^{\prime}$ is a vector of standing environmental prices for pinecones. The equation for estimating $p_{c}^{\prime}$ is similar to equation (A.2), although it is adapted to consider that pinecones are an annual output by including a corrected expansion factor, where $\left(Y_{j} / Y_{d}\right)$ represents the expansion factor for pinecones yield that relates the pinecones yield of a tree of diameter class $d\left(Y_{d}\right)$ with the pinecones yield of that same tree at a diameter class $j$ to be reached; and $\left(x_{j} / x_{d}\right)$ addresses the correction due to differences in the time length (years) that a pine belongs to a diameter class $d\left(x_{d}\right)$ and to the successive diameter classes $j\left(x_{j}\right)$ (Table A.4).

Two pinecones yield functions are taken into account, one to estimate the biological pinecones yield and one to estimate the production of commercial interest (Table A.4). For the second case, we assume that only the trees that produce at least five pinecones will be 
harvested ${ }^{5}$. The data over the number of pine trees per hectare with five or more pinecones also come from Montero et al. (2004). This study considers Stone pine plantations with a medium tree density $\left(\approx 700\right.$ tree $^{-1} a^{-1}$.

It is worth to mention that the Eqs. A.2 to A.4 could be applied to estimate the capital value of work-in-progress timber and the pinecones biological resources in the accounting year, irrespectively of the age of pines and the structure of stand (even aged or uneven aged stands).

Table A.4 Diameter classes' length, mortality and fire risk rates and yield expansion factors for timber and pinecones

\begin{tabular}{|c|c|c|c|c|c|c|c|c|c|}
\hline \multirow{3}{*}{$\begin{array}{l}\text { Diam } \\
\text { e-ter } \\
\text { class } \\
(\mathrm{cm})\end{array}$} & \multicolumn{4}{|c|}{$\begin{array}{l}\text { Diameter classes length } \\
\text { (years) }\end{array}$} & \multicolumn{2}{|c|}{$\begin{array}{l}\text { Mortality and } \\
\text { fire risk rates } \\
(\%)^{(\mathrm{a})}\end{array}$} & \multicolumn{3}{|c|}{$\begin{array}{l}\text { Yield expansion factor } \\
\text { for diameter class } 10\end{array}$} \\
\hline & \multirow{2}{*}{$\begin{array}{l}\text { Age at } \\
\text { the } \\
\text { beginni } \\
\text { ng }\end{array}$} & \multirow{2}{*}{$\begin{array}{l}\text { Age } \\
\text { at the } \\
\text { end }\end{array}$} & \multirow{2}{*}{$\begin{array}{c}\text { Aver } \\
\text { a-ge } \\
\text { age }\end{array}$} & \multirow{2}{*}{$\begin{array}{l}\text { Leng } \\
\text { th of } \\
\text { the } \\
\text { class }\end{array}$} & \multirow[t]{2}{*}{$\begin{array}{l}\text { Mortal } \\
\text { ity rate }\end{array}$} & \multirow[t]{2}{*}{$\begin{array}{l}\text { Fire } \\
\text { risk }\end{array}$} & \multirow{2}{*}{$\begin{array}{l}\text { Timb } \\
\text { er } \\
\text { yield } \\
\left(V_{j} / V_{d}\right.\end{array}$} & \multicolumn{2}{|c|}{$\begin{array}{c}\text { Pine cones }\left[\left(Y_{j} / Y_{d}\right)\right. \\
\left.\left(x_{j} / x_{d}\right)\right] \cdot\end{array}$} \\
\hline & & & & & & & & $\begin{array}{c}\text { Biologica } \\
1 \text { yield }\end{array}$ & $\begin{array}{c}\text { Commerc } \\
\text { ial yield }\end{array}$ \\
\hline 10 & 1 & 10 & 6 & 9 & 16.7 & 2.9 & 0.0 & 0.0 & 0.0 \\
\hline 15 & 11 & 26 & 18 & 15 & 6.5 & 4.6 & 6.5 & 8.2 & 12.3 \\
\hline 20 & 27 & 49 & 38 & 22 & 6.4 & 7.1 & 2.6 & 2.3 & 3.1 \\
\hline 25 & 50 & 80 & 65 & 30 & 7.7 & 9.6 & 1.8 & 2.4 & 2.9 \\
\hline 30 & 81 & 108 & 95 & 27 & 6.6 & 8.4 & 1.5 & 2.6 & 3.2 \\
\hline 35 & 109 & 121 & 115 & 12 & 3.0 & 3.7 & 1.3 & 2.2 & 2.5 \\
\hline 40 & 121 & 132 & 127 & 11 & 2.7 & 3.4 & 1.2 & 1.2 & 1.2 \\
\hline 45 & 133 & 142 & 137 & 9 & 2.2 & 2.8 & 1.1 & 1.2 & 1.2 \\
\hline 50 & 143 & 151 & 147 & 8 & 2.0 & 2.5 & 1.1 & 0.9 & 0.9 \\
\hline
\end{tabular}

Note: ${ }^{(a)}$ Mortality and fire risk for the entire diameter class.

Source: Own elaboration based on Montero et al. $(2004 ; 2008)$.

\subsection{Land capital value from timber and pinecones}

The total land value reflects the present value of the expected infinite stream of environmental incomes (European Commission et al., 2012) from timber, pinecones, private amenities, carbon sequestration, public recreation and landscape. Part of this value is considered into the work-in-progress timber (WPt) and the pinecones biological resources $\left(F C b r_{c}\right)$. The land fixed capital value $(F C l)$ reflects only the timber or pinecone values related

\footnotetext{
${ }^{5}$ For manual harvesting, pinecones collectors should normally climb up trees, thus harvesting profitability depends on the number of pinecones that could be collected.
} 
to future Stone pine rotations, as it is assumed that the afforestation project bears to a permanent Stone pine forest.

The land capital value from timber and pinecones (indexed by $k$ where $\mathrm{K}=\{1,2\}$ ) is estimated as the expected infinite flow of timber and pinecones environmental incomes $\left(E C I_{k}\right)$. Thus, the partial land fixed capital value $(F C l)$ related to timber and pinecones yield over the future Stone pine rotations is estimated formally as:

$F C l=\sum_{k=1}^{K} \sum_{s=t}^{\infty} \frac{E C I_{k}(s)}{(1+r)^{(s-t)}}-F C b r_{c}-W P t$

\subsection{Land capital value from non-market private and public uses}

The land capital value from private amenities, landscape, recreational services and carbon are estimated considering exclusively the expected infinite flow of their environmental incomes (ECI) since no work-in-progress or biological resources are associated to those outputs. Expected variation in land capital values along the accounting years are related only to timber, pinecones and carbon sequestration as their yields depend on tree growth and age. The values estimated for landscape, public recreation and private amenities do not depend on the age of the Stone pine forest as preferences can be estimated for a specific year and we assume that remain constant in the future.

\subsection{Carbon environmental asset value}

The carbon asset at the beginning of the accounting period $(V c i)$ is estimated as:

$V c i=\sum_{d=1}^{m} V c i_{d}=\sum_{d=1}^{m}\left(\alpha \cdot V i_{d} \cdot t_{d} \cdot \emptyset_{d} \cdot p_{c}^{d} \cdot(1+r)^{\left(t_{d}-E_{j}-1\right)}\right)$

Where $\alpha$ is a constant parameter that relates the timber volume (in $\mathrm{m}^{3}$ ) with the carbon stock (in $\mathrm{t} \mathrm{CO}_{2}$ ); $V i$ the initial timber stock (in $\mathrm{m}^{3}$ ) for the trees belonging to each one of the $d$ diametric classes; $\emptyset$ defines the relation between the annual carbon increase $(\Delta C)$ and the carbon stock $(S)$ for a single tree belonging to the diametric class $\left(\emptyset_{\mathrm{d}}=\Delta \mathrm{C}_{\mathrm{d}} / \mathrm{S}_{\mathrm{d}}\right), p_{c}^{d}$ is the carbon price ( $€ \mathrm{t} \mathrm{CO}_{2}^{-1}$ ), $E$ the lifespan (in years) of the diametric class.

The carbon price considers the conditional probability of a tree of the diameter class $d$ to be alive at each one of the subsequent $j$ diameter classes to be reached and an expansion 
factor $f_{s i}$ that relates carbon stock of a tree of diameter class $d$ and to each one of the diameter classes $\mathrm{j} \geq \mathrm{d}$ to be reached.

$p_{c}^{d}=\sum_{j=d}^{m} \frac{p \cdot \pi_{j d} \cdot f_{s i}}{\left.(1+r)^{(t} d^{-t j}\right)}$

where $p$ is the price per $\mathrm{CO}_{2}$ carbon paid in the accounting period. Finally, the carbon asset at the end of the accounting period $(V c f)$ is estimated as:

$V c f=\sum_{d=1}^{m} V c f_{d}=\sum_{d=1}^{m}\left(\alpha \cdot V f_{d} \cdot t_{d} \cdot \emptyset_{d} \cdot p_{c}^{d} \cdot(1+r)^{\left(t_{d}-E_{j}\right)}\right)$

where Vf is the final timber volume (in $\mathrm{m}^{3}$ ).

\section{Manufactured Stone pine forest assets}

The fixed manufactured assets include the value of plantation investment, construction and equipment. Private manufactured fixed assets account for plantation investment and private constructions. The private constructions include timber extraction paths, and account for value of $€ 10 \mathrm{ha}^{-1}$. No equipment is assigned to timber or pinecones harvest since these operations are under the responsibility of third parties (see point 2.1). The plantation investment amounts $€ 1,300 \mathrm{ha}^{-1}$ in year 2008, and it is amortized considering an annual depreciation of 1/120 part of this investment, which price is assumed to remain constant over the analyzed accounting years.

According to Campos et al. (2005) and Oviedo et al (2010) in 2002 the immobilized manufactured capital (estimated as the sum of fixed assets and working capital) used by the Andalusian government for providing forest's firefighting and public recreational services in Cadiz oak woodlands, attain to $€ 1.99 \mathrm{ha}^{-1}$ and $€ 24.20 \mathrm{ha}^{-1}$ respectively in year 2002 . Those manufactured immobilized capital values are updated to 2008 considering the Regional Forest Plan Implementation costs real variation for the period 2002- 2008, and assuming that the annual investment in these assets matches with their annual capital withdrawal and amortization, thus variations on their value are entirely due to pure prices changes. It is estimated that the Andalusian government maintains an immobilized manufactured assets priced in $€ 62.17 \mathrm{ha}^{-1}$ of Stone pine forest, to provide landscape and $€ 54.52 \mathrm{ha}^{-1}$ to provide public recreational services. 


\section{Disaggregated results}

Table A.5 Total social income distribution by Stone pines age (euro per hectare, year 2008)

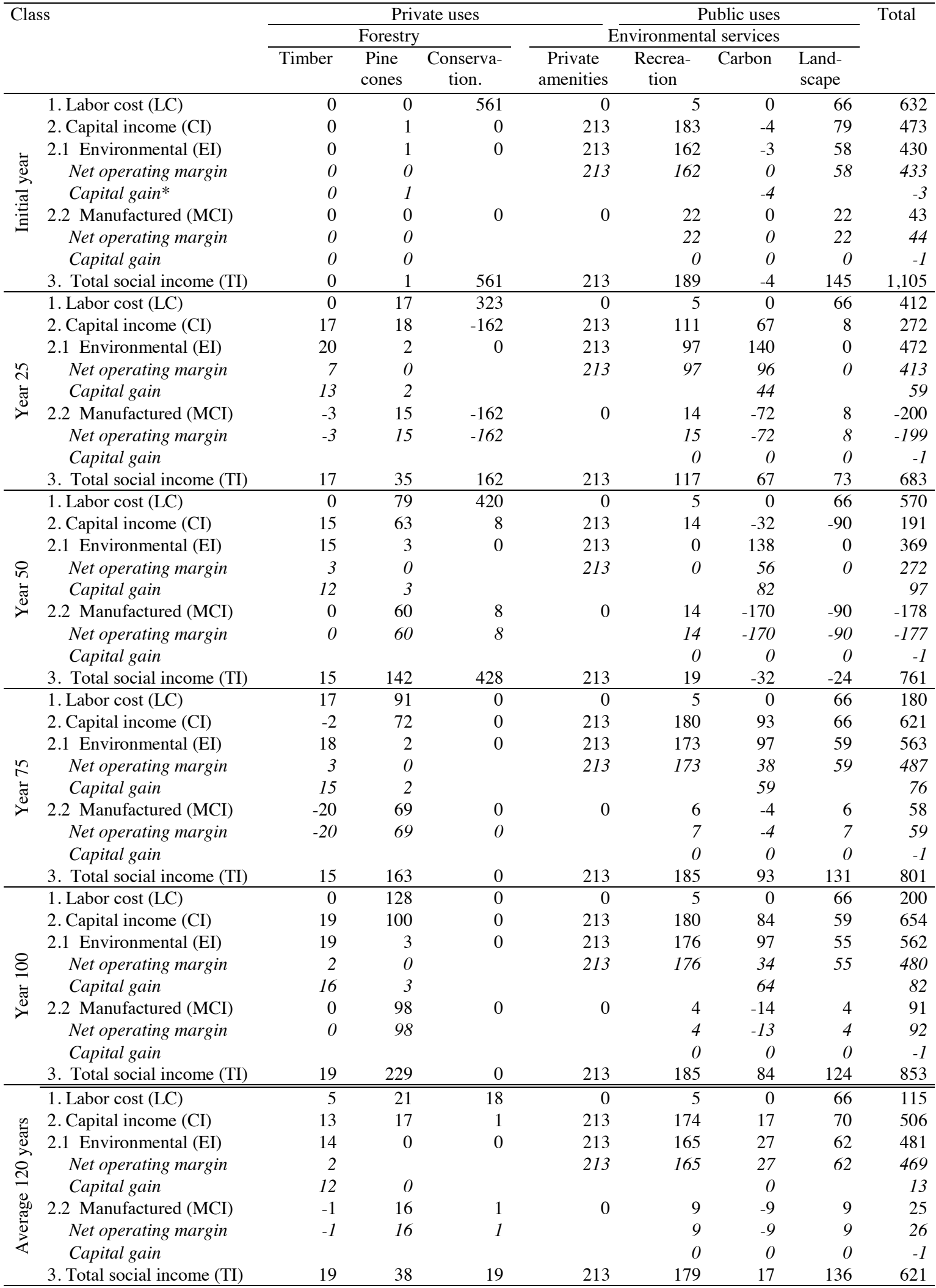

*Discount rate (r) applied to estimate capital gain: $3 \%$. 
Table A.6 Total output and costs by use and Stone pines age (euro per hectare, year 2008)

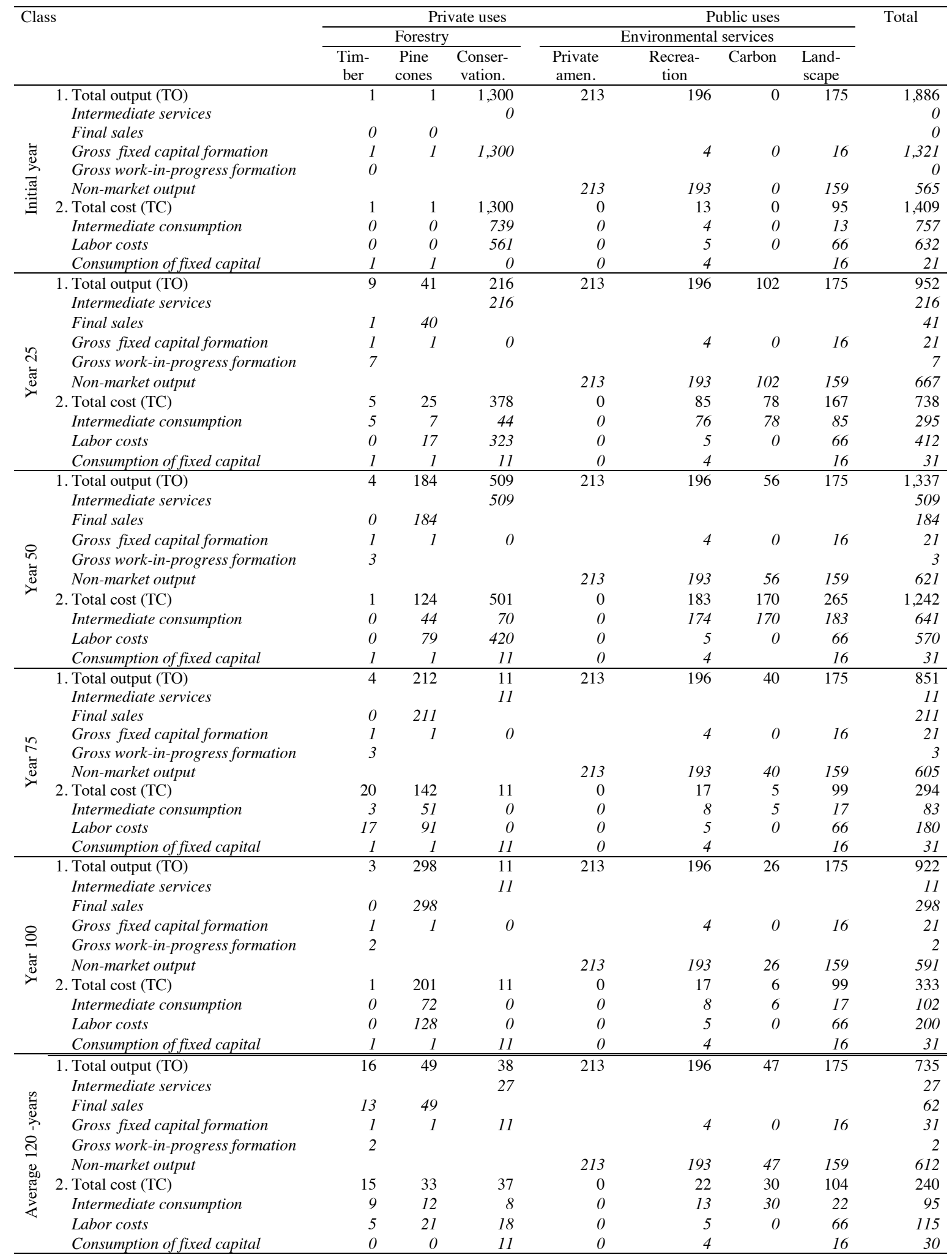




\section{References Supplementary Material}

Boletín Oficial de la Junta de Andalucía (BOJA), 2008. Orden de 25 de febrero de 2008, por la que se establecen las bases reguladoras de la concesión de ayudas para la gestión forestal sostenible de los montes en el ámbito de la Comunidad Autónoma de Andalucía. BOJA 21, de 19 de junio de 2008, 6-43.

Campos, P., Oviedo, J. L., Caparrós, A., 2005. Un sistema de cuentas para la valoración de los efectos comerciales y ambientales del gasto público en la mitigación del fuego en el bosque mediterráneo. Investigación Agraria: Sistemas y recursos Forestales 14(1), 120131.

Campos, P., Oviedo, J.L., Caparrós, A., Huntsinger, L., Seita-Coelho, I., 2009. Contingent Valuation of Woodland-Owner Private Amenities in Spain, Portugal, and California. Rangeland Ecology and Management 62(3), 240-252.

Consejería de Medio Ambiente (CMA), 2002. Memoria 2002. Plan Forestal Andaluz. Junta de Andalucía, Fondo Europeo Agrícola de Desarrollo Rural. Available online: http://www.juntadeandalucia.es.

Consejería de Medio Ambiente (CMA), 2008. Memoria 2008. Plan Forestal Andaluz. Junta de Andalucía, Fondo Europeo Agrícola de Desarrollo Rural. Available online: http://www.juntadeandalucia.es.

Díaz-Balteiro L., Caparrós A., Campos P., Almazán E., Ovando P., Álvarez A., Voces R., Romero C., (in revision). Economía privada de productos leñosos, frutos industriales, bellota, pastos y el servicio del carbono en los sistemas forestales de Andalucía. In: Economía y selviculturas de los montes de Andalucía (Campos P., Díaz-Balteiro L., eds). Memorias científicas de RECAMAN. Volumen 1. Memoria 1.3. Forthcoming.

European Commission (ECC), Food and Agriculture Organization, International Monetary Fund, Organization for Economic Cooperation and Development, United Nations, World Bank, 2013. System of Environmental and Economic Accounting-Experimental Ecosystem Accounting (SEEA-EEA).White cover publication, pre-edited text subject to official editing.

Montero, G., Candela, J.A., Rodríguez, A. 2004. El pino piñonero (Pinus pinea L.) en Andalucía. Junta de Andalucía. Seville

Montero, G., Calama R. and Ruiz-Peinado, R., 2008. Selvicultura de Pinus pinea L. In: Serrada, R., Montero, G., Reque, J. (eds.): Compendio de Selvicultura Aplicada en España. INIA-FUCOVASA. Madrid, pp.431-470. 
Navarro, R. M., Blanco, P., 2006. Estimation of above-ground biomass in shrubland ecosystems of southern Spain. Investigación Agraria: Sistemas y Recursos Forestales 15(2), 197-207.

Oviedo, J., Campos, P., Caparrós, A., 2010. Simulated Exchange Value Method: Applying Green National Accounting to Forest Public Recreation. Instituto de Políticas y Bienes Públicos (IPP) Working paper series, Number 16. Available online: http://hdl.handle.net/10261/28915

Oviedo J.L., Campos P., Caparrós A., (in revision). Valoración de servicios ambientales privados de propietarios de fincas agroforestales de Andalucía. En: Renta total y capital de las fincas agroforestales de Andalucía (Campos P., Ovando P., eds.). Memorias científicas de RECAMAN. Volumen 4. Memoria 4.1. Forthcoming. 